\title{
CRIMINAL FASHION LAW: INTERVENÇÃO PENAL NA INDÚSTRIA DA MODA
}

Tese de Doutorado

Orientador: Professor Titular Renato de Mello Jorge Silveira

Faculdade de Direito da Universidade de São Paulo

2020 


\section{REGINA CIRINO ALVES FERREIRA DE SOUZA}

\section{CRIMINAL FASHION LAW: INTERVENÇÃO PENAL NA INDÚSTRIA DA MODA}

Tese apresentada como requisito parcial para obtenção do título de Doutora em Direito Penal no curso de Pós-Graduação da Faculdade de Direito da Universidade de São Paulo.

Orientador: Professor Titular Renato de Mello Jorge Silveira

Faculdade de Direito da Universidade de São Paulo 
"A moda imita-se a si própria. Ao elevar o efémero ao estatuto de culto, ela troça, em última instância, das muitas pretensões morais da cultura dominante, que, por sua vez, a denunciam em razão da frivolidade superficial, não obstante secretamente sentirem a forma como ela afecta toda a questão moral. A moda é levada à letra e é simultaneamente posta de lado como constituindo um assunto trivial, numa tentativa para neutralizar a picada da sua verdadeira seriedade, a sua forma sub-reptícia de desmascarar a hipocrisia”.

(Elizabeth Wilson) 


\section{RESUMO}

A indústria da moda, mormente o setor têxtil e de confecção, economicamente relevante para o Brasil, revela uma série de particularidades que, por si só, justificaria um olhar diferenciado do direito para as problemáticas ali presentes, sendo assim denominado de fashion law. No entanto, dado que o país reúne a cadeia produtiva completa dentro de suas fronteiras, ou seja, atua no pré-consumo, consumo e pós-consumo (desde a produção da matéria prima até o descarte de resíduos), acrescem-se vulnerabilidades e potencialidades de riscos jurídicos. Em particular, verifica-se uma série de problemáticas de alcance jurídico-penal, dentre elas, a violação da propriedade imaterial, os crimes ambientais e a exploração laboral, situações que, uma vez não mitigadas, podem redundar, não só propriamente em punições criminais, mas impactar diretamente em ativos intangíveis, como o comprometimento da imagem empresarial, bens incorpóreos essencialmente relevantes para marcas de moda. Reconhece-se, assim, a necessidade de estudo do criminal fashion law, ou seja, o direito penal na indústria da moda e do criminal compliance como instrumento de prevenção e preservação da reputação corporativa de empresas de moda.

Palavras-chave: Fashion Law - Direito da Moda - Direito Penal da Moda - Reputação Corporativa - Compliance 


\begin{abstract}
The Fashion industry, specially the textile and garment factory, which is financially relevant in Brazil, reveals several details that, by itself, would justify a distinctive legal approach to the issues regarding the sector, therefore called fashion law. However, considering that Brazil has the entire productive chain inside its borders, that is, it operates in pre-consumption, consumption and post-consumption (from feedstock production until residues disposal), it increases the vulnerabilities and potential legal risks. In particular, there are a number of issues involving the criminal area including the violation of intellectual property, environmental crimes and exploration of the workforce, situations that, without being mitigated, may result not only in criminal punishments, but could also directly impact the company's intangible assets, such as jeopardizing the corporate identity, which are extremely relevant assets to fashion brands. Therefore, it's acknowledged the necessity of the study of criminal fashion law, this is, the study of criminal fashion law and also the criminal compliance as resources to secure and preserve corporate reputation of fashion companies.
\end{abstract}

Keywords: Fashion Law - Fashion Law - Criminal Fashion Law - Corporate Reputation - Compliance 


\section{RIASSUNTO}

L'industria della moda, in particolare il settore tessile e dell'abbigliamento, economicamente rilevante per il Brasile, rivela una serie di particolarità che, di per sé, giustificherebbero uno sguardo differenziato dalla legge ai problemi che vi si presentano, chiamandosi così fashion law. Tuttavia, dato che il paese presenta l'intera catena di produzione all'interno dei suoi confini, in altre parole, agisce in pre-consumo, consumo e post-consumo (dalla produzione di materie prime allo smaltimento dei rifiuti), vi sono ulteriori vulnerabilità e potenziali rischi legali. In particolare, ci sono una serie di questioni di diritto penale, tra cui la violazione della proprietà immateriale, $\mathrm{i}$ crimini ambientali e la splorazione del lavoro, situazioni che, una volta non mitigate, possono comportare non solo sanzioni penali, ma anche un impatto diretto su fattori intangibili, come la compromissione dell'identità aziendale, attività immateriali essenzialmente rilevanti per i marchi di moda. Pertanto, è riconosciuta la necessità di studiare il criminal fashion law, cioè la legge penale nel settore della moda e la criminal compliance come strumento per prevenire e preservare la reputazione aziendale delle aziende di moda.

Parola chiave: Fashion Law - Diritto della moda - Diritto penale della moda Reputazione aziendale - Compliance 


\section{SUMÁRIO}

INTRODUÇÃO

1. Historiografia do fashion law e as particularidades da indústria da moda no Brasil.......... 15

1.1. O mundo da moda como problema jurídico: o redesenho por Susan Scafidi à

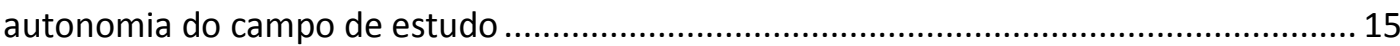

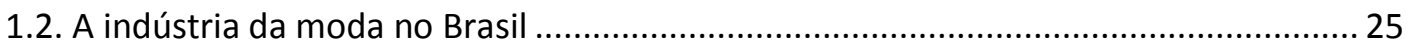

1.2.1. O desenvolvimento do setor têxtil e de confecção brasileiro................................ 31

1.2.1.1. A imigração como fator de pujança do setor de confeç̧ão: o caso da cidade

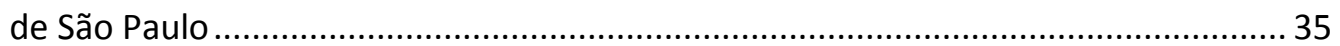

1.2.2. O cenário atual do setor têxtil e de confeç̧ão no Brasil....................................... 38

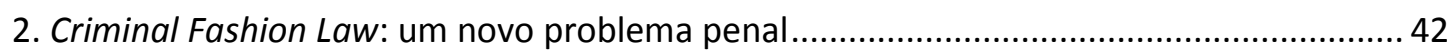

2.1. A valorização do imaterial e a conformação do criminal fashion law .......................... 43

2.2. Crimes contra a propriedade imaterial no setor de moda e luxo ................................ 49

2.3. O trabalho análogo ao de escravo nas confecções de produtos de moda ....................63

2.3.1. Redução a condição análoga à de escravo: a evolução do tipo penal e o reforço

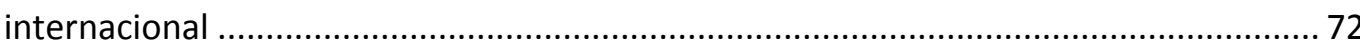

2.3.2. Responsabilidade penal no crime de redução a condição análoga à de escravo 74

2.3.2.1. Causas de aumento de pena e proposta de lege ferenda.............................. 83

2.3.3. Medidas extrapenais para o enfrentamento da questão ...................................... 84

2.3.3.1. A Lei Bezerra e outras iniciativas paradigmáticas .......................................... 84

2.3.3.2. As listas emitidas pelo Ministério do Trabalho ................................................ 86

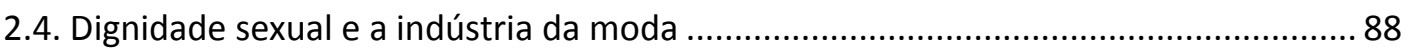

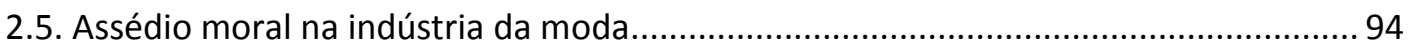

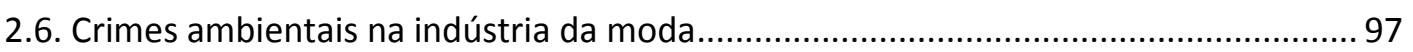

2.7. Lavagem de dinheiro e o mercado de luxo e joias ........................................................ 106

3. A reputação corporativa nas empresas de moda: o dano reputacional atrelado ao crime

3.1. A relevância da reputação corporativa como ativo intangível nos negócios de moda

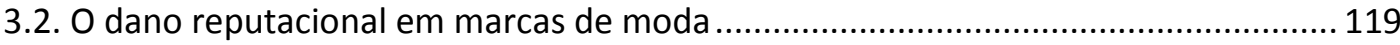

3.3. Violação de direitos humanos e dano reputacional.................................................... 131

3.3.1. O caso da Nike, Inc.: do dano ao ganho reputacional ....................................... 134

3.3.2. A importância da comunicação verdadeira: greenwashing na indústria da moda 
4.1. Tracejado histórico do criminal compliance

4.1.1. Criminal compliance na lei anticorrupção.

4.2. A prevenção de crimes na indústria da moda 154

4.2.1. Criminal compliance e o ideário de responsabilidade social corporativa na moda 159

4.2.2. O movimento pela transparência na indústria da moda 170

4.2.3. Código de conduta e políticas em empresas de moda 177

CONCLUSÃO 185

BIBLIOGRAFIA 190 


\section{INTRODUÇÃO}

Comumente os escritos sobre moda, no intento de explicar seu significado, buscam a etimologia do termo - do latim, modus, modo, maneira - e, ainda que com dificuldades para defini-la, chega-se à compreensão de que esta pode ser assimilada como a mudança periódica no estilo. Isto é, um incansável abandono do passado e da tradição para encontrar o novo, um instrumento de diferenciação e de reconhecimento de identidades. Nesse cenário, a vestimenta é apenas uma maneira de manifestação, mas a moda mostra-se mais abrangente, influenciando o cotidiano, algo perceptível nos modelos dos veículos, nos eletroeletrônicos, na decoração, na arte, na política e na ciência.

Moda, para ser assim considerada, deve pressupor a coletivização, pode partir de algo autoral ou conceitual, mas que ultrapassa o olhar atento dos experts e notáveis entendedores e suscitar o desejo público de aprovação coletiva. Em realidade, como um círculo virtuoso ou vicioso, os formadores de opinião (endorsers) buscarão novas criações para se distinguirem da massa. Intrigantes, neste aspecto, são os seus paradoxos.

Impõe-se, assim, a primeira reflexão: a moda pode parecer para poucos, mas deve sensibilizar muitos; ela busca ser exclusiva, mas é o gosto público que torna quem ela é, moda. É verdade que, no princípio, pode partir do seletivo e excludente, mas, ao final, figura como instrumento de pertencimento, servindo para, a um só tempo, se confundir com determinado grupo social e se diferenciar dos demais ${ }^{1}$. Nas palavras de Gilda de Mello, ela "reconcilia o conflito entre o impulso individualizador de cada um de nós (necessidade de afirmação como pessoa) e o socializador (necessidade de afirmação como membro do grupo)"’2.

\footnotetext{
1 "O corpo constituído com a moda nos torna culturalmente visíveis, mediante o engendramento cultural de cada período, de cada cenário, de cada lugar de existência”. AVELAR, Suzana; VICENTINI, Claudia Garcia, Moda contemporânea: algumas considerações iniciais sobre moda, cultura digital e indústria 4.0, in: Fashion law: direito da moda, São Paulo: D'Plácido, 2019, p. 348.

${ }^{2}$ SOUZA, Gilda de Mello e, $O$ espírito das roupas: a moda no século dezenove, São Paulo: Schwarcz, 1984, p. 29.
} 
No início, a moda era restrita a grupos sociais mais abastados, no entanto, com a revolução industrial ganhou abrangência aproximando-se de outras classes sociais, ao menos no que toca ao estilo de vestir, já que a qualidade, materiais e acabamento seguiam como elementos diferenciadores de classes sociais. Transportando para a realidade atual, se a moda pode ser excludente ao limitar, por exemplo, com altos preços, quem será seu público consumidor, por meio de modelos de negócio como aquele denominado fast fashion, possibilita a outros grupos receber, de forma acessível, essas informações.

Repleta de contradições, a moda circula conforme a cultura, os valores de uma época e acompanha a evolução da sociedade, sendo um claro retrato do momento vivido. A título de exemplo, relembre-se do desaparecimento das meias finas no período da Segunda Guerra Mundial. Não se tratava de um novo gosto das mulheres por não usar esses adereços, mas, naquele contexto bélico, as fibras têxteis precisavam ser destinadas à fabricação de materiais de guerra, como paraquedas, barracas e cordas, levando a que as mulheres fossem encorajadas a doarem suas meias para essa finalidade. Daí a origem da célebre frase: “Uncle Sam needs your dircarded silk and nylon stockings for gun poder bags. Please launder and leave here", ou seja, "Tio Sam precisa de suas meias de seda e nylon descartadas para sacos de pólvora. Por favor, lave-as e deixe-as aqui”.

No momento atual, igualmente a demonstrar como a moda reflete o zeitgeist, nota-se a adesão das ruas por vestimentas na cor verde-musgo, camuflagens e casacos com botões que remetem a uniformes militares. Tal não se deve ao acaso, mas a militarização do vestir é reflexo do conflituoso espírito deste tempo. Quanto a isso, as leituras que podem ser feitas são diversas, desde a tomada desse movimento como um estado de alerta permanente, a agressividade ou a resistência. Seja qual for a interpretação, claro está que a moda é um importante elemento de comunicação.

Igualmente, ainda a demonstrar como a moda está conectada com o momento político-social, percebe-se diuturnamente a busca por uma moda mais democrática, inclusiva e que respeite as diversidades, sustentável, transparente e responsável. Não são raros assim os exemplos de marcas de moda atentas ao desenvolvimento de coleções genderless (moda sem gênero) e ageless (moda sem 
idade) e que investem em desfiles plurais. Do mesmo modo, nota-se o crescimento de empresas que têm investido no capital humano e na sustentabilidade, sobretudo com a adoção de novas tecnologias para o desenvolvimento fibras menos poluentes ou para que possibilitem o rastreamento da cadeia produtiva.

Essa nova postura empresarial em hastear bandeiras como da preocupação socioambiental e da maior transparência nas operações, mostra-se como resposta aos novos anseios da sociedade contemporânea e as demandas do novo consumidor, o qual, ao ter acesso a toda soma de bens e a diversidade de produtos, aprecia e valoriza não apenas as características manufatureiras industriais como qualidade de fabricação e funcionalidade, mas também o seu valor incorpóreo, como o design, bem como o seu significado imaterial.

Ainda, nesse contexto de endossos e incentivos para a mudança de cultura empresarial de valorização de intangíveis, também é particularmente relevante a percepção de outras partes interessadas (stakeholders), como acionistas, da mídia, das associações e dos movimentos não governamentais. Em mundo globalizado e de rápida informação esses agentes são especialmente determinantes para impulsionar positivamente determinada empresa, mas também, ao ter a facilidade de fala bastante oportunizada pelas redes sociais, podem fragilizar ou comprometer a imagem corporativa por uma exposição negativa.

A sinalizar que as empresas de moda não podem mais lidar com os problemas atuais da maneira de outrora, menciona-se que escândalos corporativos nos mais diversos setores da economia, como o envolvimento de uma pluralidade de empresas de moda em casos de exploração laboral, reforçaram o movimento de que as empresas devem, ademais de promover negócios, contribuir positivamente para com a sociedade, minimizando danos e empreendendo esforços para o perfazimento de comportamentos responsáveis.

Neste contexto, a responsabilidade social corporativa diuturnamente tem sido aventada como estratégia empresarial para manter a reputação empresarial, valorizar a imagem e ganhar competitividade. 
Esses sinais dos novos tempos têm sensibilizado e influído para que novos modelos de negócios surjam, bem como para a adoção de novas estratégias empresariais. Do mesmo modo, esse novo contexto não mais permite que as questões jurídicas, antes descuidadas ou abordadas de forma periférica, sejam tratadas de maneira divorciada do negócio. O direito, visto, no mais das vezes, como um órgão estranho ao ente artificial, nos dias atuais, exerce papel fundamental não apenas como forma de resolução de conflito, mas estrategicamente para evitar riscos que possam impactar financeiramente ou na estigmatização empresarial.

Essa máxima de integrar o direito ao negócio se mostra fundamental para qualquer setor da economia, mas para a indústria da moda é singularmente relevante, tendo em vista que, geralmente, o elemento "marca" é tão ou mais importante que os seus próprios ativos tangíveis, tal como maquinário, imóvel, veículos e estoque.

Ainda, nota-se que, no Brasil, tendo em vista tratar-se da segunda maior empregadora da indústria de transformação, está mais suscetível a problemáticas trabalhistas, crimes contra as relações de trabalho e infortúnios relacionados a exploração laboral. Do mesmo modo, tendo em vista a informalidade bastante presente na longa cadeia de produção, constata-se uma maior probabilidade da ocorrência de problemáticas jurídicas, como aquelas de ordem tributária, ambiental e criminal.

Do mesmo modo, a justificar um olhar jurídico diferenciado e integrado a estratégia empresarial, vê-se, como mencionado, que o consumo de produtos de moda está ligado a fatores imateriais e a significados, estando essa indústria muito mais exposta aos efeitos negativos da depreciação do valor incorpóreo se comparada com outros segmentos, sujeitando-se aos escrutínios e rejeição do público consumidor que são muito mais atentos e sensíveis as (in) coerências da identidade corporativa.

A esse fenômeno, ou seja, analisar o direito na indústria da moda, dá-se o nome de fashion law e, não obstante englobe a percepção jurídica dos mais diversos ramos do direito, focar-se-á nos problemas penais mais sintomáticos que têm acompanhado esse setor, sendo aqui denominado de criminal fashion law. 
Neste sentido, a investigação científica perpassa por específicas questões fundamentais, as quais, subdivididas em quatro capítulos, subsidiarão as conclusões desejadas. A saber:

No Capítulo 1, após panorama acerca da origem do que se convencionou denominar fashion law e os fundamentos pelos quais vem sendo tratado como objeto de estudo em diversos ordenamentos, a justificar, inclusive, na concepção de alguns autores, a autonomia como campo de estudo. Ainda, tratar-se-á do histórico da indústria da moda no Brasil e as específicas dificuldades enfrentadas pelo setor têxtil em razão de medidas protecionistas impostas ao país.

Do mesmo modo, será observado como o setor, sobretudo a partir da produção da fibra natural de algodão, acabou por se desenvolver como indústria relevante, reunindo hoje a maior cadeia completa do ocidente, isto é, contemplando desde a produção da matéria prima até o varejo de moda. Do mesmo modo, será observado, em linhas gerais, como a imigração teve um papel fundamental para a consolidação de confecções em grandes centros urbanos como é o caso da cidade de São Paulo.

Ao final do capítulo, será traçado o retrato atual do setor e o delineamento de algumas problemáticas jurídicas mais sintomáticas para as empresas de moda.

Neste esteio, uma vez identificadas algumas das particularidades da indústria da moda, bem como revelada sua importância econômica para o Brasil, serão analisadas no Capítulo 2 algumas das questões jurídico-criminais mais sensíveis para o setor, sobretudo pelo impacto proporcionado para a imagem reputacional, isto é: os crimes contra a propriedade imaterial; o preocupante tema do trabalho análogo ao de escravo nas confecções brasileiras; o crime de assédio sexual; a proposta de criminalização do assédio moral; os crimes ambientais e o crime de lavagem de dinheiro no setor de joias e luxo.

No Capítulo 3 será abordada a importância dos ativos intangíveis para as empresas de moda, como a identidade, a imagem e a reputação corporativa. Do mesmo modo, será analisado o impacto do delito cometido na seara empresarial de um negócio 
de moda, visto que, ademais das consequências como a sanção criminal da pessoa física ou a possibilidade de responsabilização do ente coletivo nas infrações de natureza ambiental, dada a publicização negativa, pode acarretar o dano reputacional.

Por fim, no Capítulo 4, será observado o criminal compliance para a indústria da moda como possível instrumento preventivo para mitigar riscos penais, evitando-se a rotulação provocada pela sanção e a preservação da reputação empresarial.

Diante do exposto, pretende-se verificar a melhor interpretação e as propostas jurídicas para o enfrentamento de específicos interesses de cunho penal na indústria da moda, mormente no país, como novel contribuição à ciência jurídica brasileira. 


\title{
1. HISTORIOGRAFIA DO FASHION LAW E AS PARTICULARIDADES DA INDÚSTRIA DA MODA NO BRASIL
}

\begin{abstract}
Sumário: 1.1. O mundo da moda como problema jurídico: o redesenho por Susan Scafidi à autonomia do campo de estudo. 1.2. A indústria da moda no Brasil. 1.2.1. O desenvolvimento do setor têxtil e de confecção brasileiro. 1.2.1.1. A imigração como fator de pujança do setor de confecção: o caso da cidade de São Paulo. 1.2.2. O cenário atual do setor têxtil e de confecção no Brasil.
\end{abstract}

A indústria da moda é particularmente relevante para diversas economias mundiais ${ }^{3}$, abarcando, dentre outros, a produção fabril, de vestuário, o segmento calçadista, de joias e da beleza. No Brasil, consoante se verificará adiante, em razão de sua história e suas riquezas naturais essa indústria sagrou-se como economicamente representativa para o país, o que impõe um olhar atento para suas filigranas e suas questões jurídicas mais sintomáticas.

\subsection{O MUNDO DA MODA COMO PROBLEMA JURÍDICO: O REDESENHO POR SUSAN SCAFIDI À AUTONOMIA DO CAMPO DE ESTUDO}

Os problemas jurídicos na indústria da moda já são preocupações reveladas em diversos ordenamentos, tal como se verifica nos Estados Unidos da América e na Europa, sobretudo na França ${ }^{4}$ e na Itália $^{5}$, em razão de sua consagrada e longínqua

\footnotetext{
${ }^{3}$ A demonstrar a relevância dessa indústria, menciona-se que o grupo Inditex, detentor de marcas como Zara, Massimo Dutti, Uterqüe e Bershka, de acordo com o índice IBEX 35, vale atualmente mais do que o Banco Santander e BBVA juntos, sendo avaliado em 85.333,93 milhões de euros na Bolsa de Madrid. Disponível em: <https://www.elespanol.com/quincemil/articulos/economia/inditex-hoy-vale-en-bolsamas-que-banco-santander-y-bbva-juntas>. Acesso em: 17 dez. 2019.

${ }^{4}$ Neste sentido, menciona-se a pioneira obra sobre o temário elaborada por Jeanne Belhumeur, fruto de sua tese doutoral, oportunidade em que trata da necessidade de criação de um "direito internacional das criações de moda". Cf. BELHUMEUR, Jeanne, Droit international de la mode, Padova: Canova Treviso, 2000, passim. Igualmente, menciona-se o trabalho de André Bertrand que aborda, sob o olhar do direito autoral, a proteção das criações de vestuário e dos artigos de moda. BERTRAND, André, Le droit d'auteur et les droits voisins, Paris: Dalloz, 1999, p. 803-832.

${ }^{5}$ Dentre outras publicações, cite-se a de Silvia Segnalini que procura fazer uma aproximação do jurista ao vocabulário da moda, criando para isso um decálogo para o mundo da moda. Para a autora "é certo que moda e direito, quando se conhecerem um pouco melhor, um não poderá ficar sem o outro". SEGNALINI, Silvia, Le leggi della moda: guida al diritto per il mondo della moda, Milano: Skira editore, 2012, p. 35. Ainda na Itália, menciona-se o trabalho de Angelo Maietta, o qual analisa os instrumentos da propriedade intelectual e propriedade industrial disponíveis no cenário europeu para proteger os resultados do engenho humano, sobretudo em relação às criações de moda. Em especial, o autor faz uma análise sobre o made in Italy e as medidas aduaneiras para coibir a contrafação. MAIETTA, Angelo, Il diritto della moda, Torino: G. Giappichelli Editore, 2018, p. 89-109. Registre-se também a obra coletiva "Il codice moda", vez que, o capítulo 6, sob a lavra de Giovanna Lucente, é dedicado a
} 
história na moda. Embora com diferentes perspectivas, todos eles tateiam soluções e alternativas para enfrentar delicadas questões, como aquelas relativas à cópia de produtos de moda e de luxo; os danos ambientais ocasionados por essa indústria altamente poluente e a sujeição de milhares de pessoas ao trabalho análogo ao de escravo em confecções.

Susan Scafidi alcunhou esse campo de estudo com o nome de fashion law, ou seja, direito da moda. A especialista norteamericana foi responsável por criar, em 2005, o primeiro blog destinado a aproximar a comunidade jurídica ao universo da moda, o "Counterfeit Chic".

Anos mais tarde, ainda revelando o seu protagonismo na matéria, Scafidi fundou o Fashion Law Institute, organização sem fins lucrativos com sede na Fordham University School of Law, pioneiro centro acadêmico do mundo dedicado ao direito e os negócios de moda ${ }^{7}$. Sem dúvidas essas iniciativas foram importantes para que outros estudos pudessem se desenvolver e para que o tema ganhasse capilaridade, revelando atualmente pesquisas em países como Nigéria ${ }^{8}$, Turquia $^{9}$, Rússia $^{10}$, Espanha ${ }^{11}$ e Portugal $^{12}$, bem como em países da América Latina como Brasil ${ }^{13}$, Argentina ${ }^{14}$, Chile, Colômbia, Peru e Uruguai.

análise da proteção penal da moda made in Italy e as estratégias para cercear as falsificações. LUCENTE, Giovanna Corrias, La tutela penal della moda made in Italy e le strategie di contraffazione, in: LICHERI, Annaluce; MASSARO, Cristiana (Orgs.), Il codice moda, Roma: Amon, 2015, p. 71-106. Do mesmo modo, necessário se faz a alusão a obra coletiva coordenada por Pozzo e Jacometti, tendo em vista que reúne artigos com temas, dentre outros, negociais, de direito do consumidor, direito do trabalho e concorrencial, sendo destaque o artigo sobre a proteção penal do trabalhador e do produto de moda. PERINI, Chiara, La tutela penale del lavoratore e del prodotto nella moda, in: Fashion Law: le problematiche giuridiche della filiera della moda, Milano: Giuffrè Editore, 2016, p. 181-208.

${ }^{6}$ Disponível em: <http://counterfeitchic.com/>. Acesso em: 19 out. 2019.

${ }^{7}$ Disponível em: <https://fashionlawinstitute.com/>. Acesso em: 19 out. 2019.

${ }^{8}$ Disponível em: <https://africafashionlaw.com.ng>. Acesso em: 19 out. 2019.

${ }^{9}$ Disponível em: <http://modahukukuenstitusu.org/>. Acesso em: 19 out. 2019.

${ }^{10}$ Disponível em: <http://fashion-law.ru>. Acesso em: 19 out. 2019.

${ }^{11}$ Disponível em: <https://www.fashionlawinstitute.es/>. Acesso em: 19 out. 2019.

${ }^{12}$ Disponível em: <http://www.fashionmeetsrights.com>. Acesso em: 19 out. 2019.

${ }^{13}$ Em 2012, foi fundado o primeiro Instituto de Direito da Moda no Brasil, qual seja, Fashion Business and Law (FBLI). Disponível em: <http://fbli.com.br/>. Acesso em: 19. out. 2019. Ainda, em 2017, foi criada a primeira pós-graduação brasileira em Fashion Law na Faculdade Santa Marcelina, pioneira no ensino de moda no Brasil e reconhecida internacionalmente como uma das melhores nessa área. Disponível em: <https://www.santamarcelina.org.br/>. Acesso em: 19 out. 2019.

${ }^{14}$ Disponível em: <http://derechodelamoda.blogspot.com/>. Acesso em: 19 out. 2019. 
Nas palavras de Scafidi o fashion law não se limita a análise de leis e regulamentos, mas também inclui regras de organizações públicas e privadas e normas sociais ${ }^{15}$. Podendo ser definido como "um campo que abarca a substância legal do estilo, incluindo as questões que podem surgir ao longo da vida de uma roupa, a partir da ideia original do criador e continua todo o caminho até o armário do consumidor" ${ }^{\circledR 16}$.

Mais que isso, o direito da moda também se preocupa com as problemáticas jurídicas presentes no pós-consumo, ou seja, com a destinação dada aos produtos de moda ao final do seu ciclo de vida. As questões jurídicas na moda perpassam, então, o pré-consumo, o consumo e o pós-consumo.

Não obstante o olhar inicial da professora tenha sido para as filigranas jurídicas envolvendo as roupas, sobretudo sob o aspecto da proteção intelectual desses bens, desde o início reconhece que o fashion law abrange também a comunicação, a modelagem e a indústria de beleza e das fragrâncias ${ }^{17}$, bem como se faz presente no setor joalheiro e calçadista.

O interesse de Scafidi por esse estudo não tradicional surgiu com a sua percepção quanto à necessidade de reformulação da legislação estadunidense em relação a proteção das criações de moda, tendo em vista que naquele ordenamento os designs têxteis e de vestuário são considerados utilitários e, portanto, no entendimento da autora, não passíveis de adequada proteção intelectual ${ }^{18}$.

Neste sentido e fazendo importante contraponto, descreve Scafidi que, enquanto um falsificador que se dedica à reprodução não autorizada de marcas registradas corre o risco de responder judicialmente e de sofrer sanções civis e

\footnotetext{
${ }^{15}$ SCAFIDI, Susan, Towards a jurisprudence of fashion, Fordham Intellectual Property, Media and Entertainment Law Journal, v. XXIX, p. 429-434, 2019, p. 433.

${ }^{16}$ SCAFIDI, Susan, Fashion law: diseñando una nueva disciplina, in: BELLO KNOLL, Suzy Inés; ECHEVERRÍA, Pamela (Orgs.), Derecho y moda, Buenos Aires: Marcial Pons, 2015, p. 19.

${ }^{17}$ SCAFIDI, Susan, Introduction: fashion law triumphant - designing sucess in a new legal field, in: Navigation fashion law: leading lawyers on developing client brands in a changing market and monitoring key legal developments, [s.1.]: Thomson Reuters/Aspatore, 2015, p. 8 (tradução livre).

18 Vale dizer que, em algumas situações, os elementos estéticos que podem ser identificados separadamente dos aspectos utilitários podem ser protegidos. A questão é que, em sua maioria, os produtos de moda, especialmente as roupas, dificilmente podem ser identificados de forma independente. BARRÈRE, Christian; DELABRUYÈRE, Sophie, Intellectual property rights on creativity and heritage: The case of the fashion industry, European Journal of Law and Economics, v. 32, n. 3, p. 305-339, 2011, p. 308.
} 
criminais, aquele que copia todos as características de uma peça de roupa, com exceção da etiqueta com a marca, está diante de uma prática comercial legal. Ou seja, cria-se uma brecha para os falsificadores, alguns dos quais, para evitar a fiscalização aduaneira, importam cópias baratas que ainda não ostentam rótulos falsificados e depois os afixam $\operatorname{nos} \mathrm{EUA}^{19}$.

Por esses e outros fundamentos, compreende Scafidi pela necessidade de modificação da legislação, tendo em vista que essas criações, ademais de utilitárias, também são criações estéticas que deveriam ser submetidas ao regime do copyright ou ao regime de proteção industrial ${ }^{20}$.

Em suas palavras, a abordagem ideal seria criar uma regulação customizada que respeitasse a complexidade da própria moda ${ }^{21}$. Neste ponto, relembrando a autora que a União Europeia confere proteção de três anos para projetos não registrados e cinco anos para os projetos registrados, sendo passíveis de renovação por um total de até vinte e cinco anos, sugere a elaboração de um modelo de proteção de curto prazo, consoante às necessidades dos consumidores e criadores ${ }^{22}$.

\footnotetext{
${ }^{19}$ SCAFIDI, Susan, F.I.T.: Fashion as information technology, Syracuse Law Review, v. 59, p. 69-90, 2008, p. 88. Neste aspecto, referencia-se o projeto de lei denominado "Counterfeit Goods Seizure Act of 2019”, de lavra dos senadores Thom Tillis, Chris Coons, Bill Cassidy e Mazie Hirono, que vislumbra conferir autoridade legal para a alfândega norteamericana (Customs and Border Protection) para apreender mercadorias de remetentes que tentem tirar proveito das brechas do sistema. Ou seja, permitiria a apreensão de mercadorias que envolvam violações de patentes de design. Embora o Brasil não tenha esse sistema de proteção, verifica-se que esse, resguardada todas as proporções, é similar ao denominado desenho industrial reconhecido pela legislação pátria. Disponível em: <https://www.congress.gov/bill/116th-congress/senate-bill/2987/all-info?r=5>. Acesso em: 08 jan. 2020. De acordo com o senador Hirono: "Embora a Alfândega e a Proteção de Fronteiras tenham autoridade para apreender produtos que violam direitos autorais e marcas comerciais na fronteira, elas não possuem essa mesma autoridade para produtos que infringem uma patente de design. Os falsificadores exploram essa brecha importando produtos falsificados separadamente dos rótulos que contêm uma marca comercial infratora, anexando-os somente quando o produto falsificado tiver despachado a alfândega. A Lei de Apreensão de Bens Contrafeitos de 2019 fecha essa brecha, dando ao CBP a autoridade para apreender produtos falsificados que infringem patentes de design na fronteira. Essa simples mudança ajudará muito a proteger os consumidores e as empresas americanas contra danos". Disponível em: <https://www.nixonpeabody.com/en/ideas/articles/2019/12/09/increased-border-enforceability-fordesign-patents>. Acesso em: 08 jan. 2020 (tradução livre).

${ }^{20}$ SCAFIDI, Susan, Intellectual property and fashion design, Intellectual Property and Information Wealth, v. 115, p. 115-131, 2006, p. 118. A discussão foi matéria do Jornal Folha de São Paulo em 2010. Intitulada de "Na forma da lei", a reportagem traz como chamada: "Senador norte-americano cria projeto de proteção à propriedade intelectual do design de moda para controlar cópias nos EUA". Disponível em: <http://www1.folha.uol.com.br/fsp/ilustrad/fq1308201015.htm>. Acesso em: 28 nov. 2019.

${ }^{21}$ SCAFIDI, F.I.T.: Fashion as information technology, p. 82.

${ }^{22}$ Ibid., p. 90.
} 
Neste esteio, menciona-se algumas proposições legislativas alinhadas com o pensamento de Susan Scafidi. Cite-se o Design Piracy Prohibition Act (DPPA), lançado pelo Parlamentar Robert Goodlatte, em março de 2006, primeiro projeto apresentado no Congresso estadunidense, com escopo de alterar Título 17 do United States Code, para ampliar o copyright aos designs de moda ${ }^{23}$.

No mesmo sentido, em agosto de 2010, foi apresentado pelo Senador Charles Schumer o Innovative Design Protection and Piracy Prevention Act (IDPPPA), com o idêntico objetivo de conferir proteção aos designs de moda, revisando a definição de "useful article" para incluir artigo de vestuário, compreendendo como tal as roupas, as bolsas, as carteiras, as sacolas, os cintos e as armações de óculos ${ }^{24}$.

Ainda, relembra-se que, em setembro de 2012, foi proposto o The Innovative Design Protection Act (IDPA), o qual, igualmente, intenciona a alteração do Título 17, estendendo a proteção pelo copyright aos produtos de moda ${ }^{25}$.

Em comum, tanto o pensamento de Scafidi como essas tentativas de estabelecimento de marcos legais revelam a intencionalidade de oferecer melhor guarida intelectual às criações de moda no ordenamento norte-americano. Aliás, esse propósito inicial, pode ser uma das explicações para a tão recorrente, embora equivocada, compreensão de que fashion law seria sinônimo ou matéria afim da propriedade intelectual, quando, como se verá adiante, é apenas uma das facetas do direito da moda.

A tutela dos direitos intelectuais, como avalia a especialista é apenas "a ponta do iceberg proverbial”26, denotando-se, assim, o espectro poliédrico da questão. O fashion law vai adiante, abarcando os direitos dos negócios e finanças, o direito do trabalho, o direito do comércio internacional e regulamentação governamental, bem

\footnotetext{
${ }^{23}$ H.R. 5055 - 109th Congress (2005-2006). Disponível em: <https://www.congress.gov/bill/109thcongress/house-bill/5055>. Acesso em: 28 nov. 2019.

${ }^{24}$ S. $3728-111^{\circ}$ Congress (2009-2010). Disponível em: <https://www.congress.gov/bill/111thcongress/senate-bill/3728>. Acesso em: 28 nov. 2019.

${ }^{25}$ S. 3523 - 112th Congress (2011-2012). Disponível em: <https://www.congress.gov/bill/112thcongress/senate-bill/3523>. Acesso em: 28 nov. 2019. Sobre a análise das distinções e semelhanças entre as propostas, vide: JIMENEZ, Guillermo C.; KOLSUN, Barbara, Fashion law: a guide for designers, fashion executives and attorneys, New York: Fairchild Books, 2013, p. 67-69. A alteração legislativa vem recebendo apoio do The Council of Fashion Designers of America (CFDA); GRUMBACH, Didier, History of international fashion, Massachusetts: Interlink Books, 2014, p. 374-375.

${ }^{26}$ SCAFIDI, Towards a jurisprudence of fashion, p. 430.
} 
como questões relativas à segurança laboral, sustentabilidade, além do direito do consumidor e os direitos civis ${ }^{27}$.

Ao que tudo indica, vivencia-se no fashion law algo próximo ao que se deu no direito desportivo, no direito de mídia e entretenimento e no setor de óleo e gás ${ }^{28}$. Isto é, tendo em vista que são setores que reúnem diversas particularidades, instiga a reflexão se deveriam ser vistos como novas áreas jurídicas.

Como bem pondera Fasson Llosa, podem ser citados como características próprias da indústria da moda e retail, dentre outros, as coleções por temporada, o processo produtivo, a expansão dos conglomerados de moda e de luxo, a luta contra a pirataria, as formas de atração de investidores, a contratação de modelos, a proteção do meio ambiente, o uso de peles animais, o método de obtenção das pedras preciosas, a valorização dos intangíveis e a importação e exportação de mercadorias ${ }^{29}$.

A manifesta interdisciplinaridade e a dependência do direito da moda de diversos ramos do direito, apoiando-se em seus princípios e regras, bem como tendo em vista compartilhar a proteção de bens jurídicos tutelados por outras áreas, são argumentos levantados pelos autores contrários ao reconhecimento da autonomia jurídica do direito da moda ${ }^{30}$.

Por outro lado, tal como relembra Abreu, embora o direito da moda observe os mesmos bens jurídicos que aqueles de outras áreas do direito, em verdade, ao se constatar as relações estabelecidas no mundo da moda e os termos utilizados, é possível vislumbrar alguma inovação jurídica, sobretudo na forma de acomodar alguns princípios do direito e, do mesmo modo, na criação de novos, em direção à autonomia e o surgimento de uma nova disciplina ${ }^{31}$.

\footnotetext{
${ }^{27}$ SCAFIDI, Introduction: fashion law triumphant - designing sucess in a new legal field, p. 8 .

${ }^{28}$ SOUZA, Regina Cirino Alves Ferreira, Direito da moda: o lado oculto da etiqueta, in: SOUZA, Regina Cirino Alves Ferreira (Org.), Direito da moda: fashion law, Minas Gerais: D’Plácido, 2019, p. 11.

${ }^{29}$ FASSON LlOSA, Annalucia, Moda sostenible o sustentable, in: SOUZA, Regina Cirino Alves Ferreira (Org.), Fashion law: direito da moda2, São Paulo: D’Plácido, 2019, p. 214 e 215.

${ }^{30}$ ABREU, Lígia Carvalho, Os princípios do direito da moda e sua relevância na construção e autonomia de uma nova disciplina jurídica, in: ABREU, Lígia Carvalho; COUTINHO, Francisco Pereira (Orgs.), Direito da moda: vol I, Lisboa: CEDIS, 2019, p. 13.

31 Ibid.
} 
Neste diapasão, são mencionados pela autora os seguintes princípios como espaços e objetos de estudo do direito da moda: o princípio do desenvolvimento sustentável; o princípio da rastreabilidade e da divulgação da origem; princípio da dignidade humana ao princípio da não discriminação; o princípio da dignidade animal; o princípio da não apropriação cultural e o princípio do respeito dos direitos de propriedade intelectual dos criadores de moda ${ }^{32}$.

Quanto à natureza jurídica do direito da moda, a autora portuguesa entende ser dupla, ou seja, tem como fonte o direito privado, na medida em que regulamenta as relações jurídicas estabelecidas entre sujeitos de direito privado, notadamente, as indústrias, as agências de modelos, os modelos, os comerciantes, os designers e os inventores ${ }^{33}$.

Do mesmo modo, também tem natureza jurídico-pública, eis que o Estado, por questões como aquelas de saúde física e psíquica pode interferir na liberdade daquele que cria ou que é modelo. Ainda, também por motivos de ordem pública, pode interferir na regulação do comércio para proteção dos direitos humanos. Desta forma, verifica-se que os sujeitos do direito da moda não são apenas pessoas singulares e coletivas privadas e nem só o direito privado é fonte de disciplina ${ }^{34}$.

A corroborar com essa linha de pensamento, menciona-se que a França, no intuito de inibir a veiculação de propagandas enganosas, exige, de acordo com a redação da LOI n 2016-41 du 26 janvier 2016 de modernisation de notre système de santé, que as alterações efetuadas por programas de edição devem conter o alerta "graphie retouchée", ou seja, imagem retocada. A punição para a omissão da advertência é de multa de 37.500 euros ou $30 \%$ do custo da propaganda ${ }^{35}$.

\footnotetext{
${ }^{32}$ Ibid., p. 13-30.

${ }^{33}$ Ibid., p. 12.

${ }^{34}$ Ibid.

35 “Art. L. 2133-2.-Les photographies à usage commercial de mannequins, définis à l'article L. 7123-2 du code du travail, dont l'apparence corporelle a été modifiée par un logiciel de traitement d'image afin d'affiner ou d'épaissir la silhouette du mannequin doivent être accompagnées de la mention: 'Photographie retouchée'. Disponível em: <https://www.legifrance.gouv.fr/eli/loi/2016/1/26/AFSX1418355L/jo\#JORFARTI000031912992>. Acesso em 08 jan. 2020. Sobre isso: SOUZA, Direito da moda: o lado oculto da etiqueta, p. 13.
} 
Para o legislador francês, as alterações realizadas em imagens, por vezes, deixam de ser apenas um fator de competição comercial desleal, mas podem estimular transtornos alimentares dos consumidores, tornando-se um problema de saúde pública. Em outras palavras, há preocupações supraindividuais em mais de um caráter, razão pela qual o Estado intervém.

Ainda como exemplo da interferência estatal na moda, recorda-se que países como Espanha, Itália ${ }^{36}$, Índia e Israel proíbem que modelos participem de desfiles de moda se o índice de massa corporal (IMC) estiver abaixo de 18,5. Isto pois, de acordo com a Organização Mundial de Saúde (OMC), o IMC inferior a esse número é sinal de alerta de que o indivíduo está com desnutrição.

No Brasil, em 2006, sobretudo após a morte de uma modelo vítima de anorexia, houve um incremento da atuação dos órgãos de controle e a maior a discussão sobre temas sensíveis, até então, silentes no mercado de modelos, como a preservação da saúde, as condições de trabalho e o estabelecimento de cotas sociais e raciais ${ }^{37}$.

Em especial, menciona-se o Termo de Ajustamento de Conduta (TAC) firmado no mesmo ano que estabeleceu como 16 (dezesseis) anos a idade mínima dos modelos para participação em desfiles de moda, sendo necessário alvará judicial para os menores de 18 (dezoito) anos ${ }^{38}$.

Em realidade, observa-se que cada realidade jurídica tende a aprofundar os estudos de direito aplicado à indústria da moda conforme suas particularidades, interesses e demandas.

\footnotetext{
${ }^{36}$ Em 2006, foi subscrito na Itália o "Manifesto Nazionale di Autrregolamentazione Della Moda Italiana Contro L'Anoressia", promovido pelo então ministra para as políticas de juventude e das atividades desportivas, Giovanna Melandri. Disponível <https://www.cameramoda.it/media/pdf/manifesto_sostenibilita_it.pdf >. Acesso em: 28 nov. 2019.

${ }^{37}$ GODOY, Mariana Hamar Valverde; COSTA, Michelle Hamuche, Direito de imagem e sua evolução com o mercado da moda no Brasil, in: SOUZA, Regina Cirino Alves Ferreira (Org.), Fashion law: direito da moda, São Paulo: D’Plácido, 2019, p. 159.

${ }^{38}$ A empresa Luminosidade, responsável por grandes eventos de moda, assinou TAC com o Ministério Público para permitir a participação apenas de modelos com idade igual ou superior a 16 anos. Disponível em: <https://ffw.uol.com.br/noticias/moda/marc-jacobs-esquenta-discussao-sobre-modelos-adolescentesem-desfiles-de-moda/>. Acesso em: 10 jan. 2020.
} 
Assim, na França, tendo em vista sua tradição na moda e a alta $\operatorname{costura}^{39}$, a atenção dada à questão da proteção intelectual é bastante acentuada, o que, inclusive, pode ser observado em termos legislativos.

Isto pois, o Código de Propriedade Intelectual francês estabelece a proteção das criações provenientes de industrias sazonais, ou seja, protege-se “(...) os direitos dos autores sobre todas as obras do intelecto humano, qualquer que seja seu gênero, forma de expressão, mérito ou destino". No artigo L112-2, faz menção à vestimenta, peleteria, roupa íntima, bordado, moda, calçado, luva, artigos de couro, à fabricação de tecidos de grande novidade ou especiais para a alta costura, à produção de joias e calçados sob medida, assim como às fabricações de tecidos para a decoração de interiores ${ }^{40}$.

Ao que parece, o legislador capturou o fato social-econômico da moda para a França e para o mundo, visto ser, além de economicamente relevante, "um dos ícones que definem o caráter e a idiossincrasia francesa" ${ }^{41}$.

No esquadro italiano, é notável a preocupação no que toca à proteção do produto made in italy ${ }^{42}$, em relação a outras mercadorias que não reúnem determinadas condições, mas que são vendidas como se legítimas fossem ${ }^{43}$. Ou seja, é natural que, ademais de outras inquietações, o enfoque do direito da moda na seara italiana esteja muito mais direcionado às questões de contrafação e de proteção dos direitos dos consumidores.

\footnotetext{
${ }^{39}$ Sobre as diferenças entre alta costura e prêt-à-porter, vide: GRUMBACH, History of international fashion, p. 207 e ss.

${ }^{40}$ De acordo com a redação francesa: "Les créations des industries saisonnières de l'habillement et de la parure. Sont réputées industries saisonnières de l'habillement et de la parure les industries qui, en raison des exigences de la mode, renouvellent fréquemment la forme de leurs produits, et notamment la couture, la fourrure, la lingerie, la broderie, la mode, la chaussure, la ganterie, la maroquinerie, la fabrique de tissus de haute nouveauté ou spéciaux à la haute couture, les productions des paruriers et des bottiers et les fabriques de tissus d'ameublement".

${ }^{41}$ PATROCINIO POLO, Hugo de, Tauromaquia y propiedad intelectual, Madrid: REUS S.A, 2014, p. 67 (tradução livre).

${ }^{42} \mathrm{O}$ made in italy é um modelo de marca e valor que se aflora em quatro setores, ditos "delle quatro A" ou " $4 A$ ", quais sejam: alimentare, abbigliamento e moda, arredo e automazione. FITTANTE, Aldo, Brand, industrial design e made Italy: la tutela giuridica: lezioni de diritto della proprietà industriale, Milano: Giuffrè Editore, 2015, p. 181 e 185.

${ }^{43}$ MAGAGNOLI, Stefano, Made in Eataly: identidà e falsificazione, in: Contraffazione e cambiamento economico: marche, imprese, consumatori, Milano: Egea, 2013, p. 77.
} 
No Brasil, a análise do direito na indústria da moda mostra-se bastante ampla e complexa, tendo em vista que ser, no que toca ao setor têxtil e de confecção, um dos únicos países que ainda reúne uma cadeia produtiva completa dentro de suas fronteiras. Por conseguinte, o país desenvolve etapas primárias, tal como a produção da matéria prima - seda, algodão, entre outras -, bem como ostenta tecelagens e estamparias e, ainda, atua nos processos de criação, modelagem e confecção e, por fim, revela um importante comércio de artigos de moda para a economia do país.

Do mesmo modo, verifica-se que no Brasil não só a indústria têxtil e de confecção são representativas, mas também o setor de beleza ${ }^{44}$, bem como tendo em vista sua riqueza natural, é notável sua importância no segmento de joias e pedras preciosas $^{45}$. Ainda, mostra-se bastante destacado o setor calçadista, dentre outros motivos, em razão de sua extensão territorial permitir a criação de gados para obtenção de couro.

Assim, dada sua grandeza, é natural que a indústria da moda brasileira também lide com questões negativas originadas em cada um desses setores e etapas de produção, ou seja, problemáticas jurídicas e reputacionais que estão presentes em toda a cadeia $^{46}$. Cite-se, neste sentido, a poluição ambiental proporcionada pelos resíduos têxteis e de curtumes brasileiros; os danos ambientais relacionados ao incorreto descarte de produtos; a deterioração das relações laborais em razão da ainda operante

\footnotetext{
${ }^{44}$ O Brasil, segundo dados da Associação Brasileira da Indústria de Higiene Pessoal, Perfumaria e Cosméticos (ABIHPEC), possui 2.794 empresas regularizadas na Anvisa. Disponível em: <https://abihpec.org.br/publicacao/panorama-do-setor-2019-2/>. Acesso em: 06 jan. 2020. A revelar a representatividade do país nesse segmento, relembre-se que a Natura \& Co, empresa brasileira especializada em de produtos de beleza, adquiriu a Avon Products, criando a quarta maior empresa de beleza do mundo. Disponível em: <https://epocanegocios.globo.com/Empresa/noticia/2020/01/epocanegocios-natura-conclui-compra-da-avon-e-cria-4a-maior-empresa-de-beleza-do-mundo.html〉. Acesso em: 06 jan. 2020. Ainda, o grupo, em 2019, celebrou a abertura da negociação de suas ações na Bolsa de Valores de Nova York (NYSE). Disponível em: <https://www.istoedinheiro.com.br/natura-co-consegueaprovacoes-para-iniciar-negociacao-de-adss-em-nova-york/>. Acesso em: 08 jan. 2020.

${ }^{45}$ Em 2018, o setor empregou 76.542 pessoas, sendo o comércio, responsável por $58 \%$ dos postos de trabalho, com aproximadamente 14.000 estabelecimentos. As vendas do varejo, em 2018, atingiram R\$ 12,6 bilhões e, até 2023 , estima-se que esse número ultrapassará $\mathrm{R} \$ 13$ bilhões. O Brasil está posicionado entre os maiores produtores de ouro do mundo, ficando na $12^{\mathrm{a}}$ posição, ficando atrás da China, Austrália, Rússia, Estados Unidos, Canadá, Indonésia, Peru, África do Sul, México, Gana e Uzbequistão. Ainda, está entre os maiores fornecedores de pedras coradas e, com exceção dos diamantes, rubis e esmeraldas, classifica-se no $2^{\circ}$ lugar do Ranking. Disponível em: <https://ibgm.com.br/publicacao/publicacao-o-setorem-grandes-numeros-2018/>. Acesso em: 06 jan. 2020.

${ }^{46}$ Sobre o temário: BAUDRILLARD, Jean, A sociedade de consumo, Rio de Janeiro: Elfos Editora, 1995, p. 24.
} 
informalidade da indústria da moda e a questão da contrafação e contrabando de mercadorias ${ }^{47}$.

Extrai-se do panorama apresentado que o estudo do fashion law, sobretudo após a contribuição de Scafidi em atribuir um nome a esse fenômeno, ganhou capilaridade e, nos dias atuais, é matéria de interesse em diversos países ${ }^{48}$. Isto é, ainda que cada localidade tenha suas demandas específicas, nota-se um movimento uníssono pela necessidade de observância do direito consoante as especificidades da moda, ventilando-se, inclusive, ideias, ainda que embrionárias, em direção do reconhecimento da autonomia jurídica do direito da moda.

Desta forma, importa para a presente análise observar a importância do direito da moda para o Brasil, isto é, a partir da análise do histórico e do alcance da indústria da moda para o país, serão observados problemas jurídicos enfrentados, enfatizando-se aqueles de natureza criminal.

\subsection{A INDÚSTRIA DA MODA NO BRASIL}

A indústria da moda no Brasil, conforme destacado revela-se de suma importância para a economia nacional, sobretudo no que toca ao setor têxtil e de confecção, cuja relevância torna necessário um olhar mais apurado.

Antes, porém, de detalhar o histórico da formação desse setor no país, importante se faz uma digressão, em linhas gerais, sobre o período de formação da

\footnotetext{
${ }^{47}$ Note-se que a Política Nacional de Resíduos Sólidos do Ministério do Meio Ambiente (PNRS), Lei $n^{\circ}$ 12.305, de 02 de agosto de 2010, que dispõe sobre seus princípios, objetivos e instrumentos, bem como sobre as diretrizes relativas à gestão integrada e ao gerenciamento de resíduos sólidos, incluídos os perigosos, às responsabilidades dos geradores e do poder público e aos instrumentos econômicos aplicáveis, não prevê a destinação correta para sobras de tecidos. Nos últimos anos, algumas empresas em parceria com universidades vêm buscando soluções para a ainda complexa reciclagem têxtil. Menciona-se que a França intenta proibir a destruição de têxteis e roupas não vendidas. Disponível em: <https://www.consultation-economie-circulaire.gouv.fr/la-feuille-de-route-economie-circulaire>. Acesso em: 24 mai. 2018. Ainda, sobre obsolescência programada vide: RUIZ, Mayra C.; ROMERO, Zilath, La responsabilidad social empresarial y la obsolescencia programada, Saber, ciencia y libertad, v. 7, p. 127135, 2013, p. 132.

${ }^{48}$ Conforme salientado anteriormente, há notícias de estudos anteriores ao de Scafidi sobre o direito aplicado à indústria da moda, mas a designação de uma nomenclatura possibilitou a expansão dos estudos e, inclusive, a aproximação de pesquisadores do tema. Neste sentido, menciona-se que, em novembro de 2018, em Madrid, foi realizado pela Fashion Law Institute Spain (FLIS) o "Primer Encuentro Internacional Fashion Law Network" reunindo especialistas e estudiosos de países como Brasil, Espanha, Portugal, França, Rússia, Turquia, Chile, Uruguai, Colômbia.
} 
moda e o surgimento das restritivas legislações suntuárias e pragmáticas, com escora de verificar os reflexos desse poder punitivo para o desenvolvimento do segmento têxtil para o país.

As mudanças ocorridas no final da Idade Média, aproximadamente entre 1350 e o início da Idade Moderna (Renascimento) foram propulsoras para o que, posteriormente, passou-se a denominar de moda. Dentre as mais significativas alterações, destaca-se a ascensão econômica dos mercadores, os quais, nos séculos XIII e XIV, em razão do desenvolvimento do comércio e do intercâmbio entre regiões, conquistaram riquezas equiparáveis àquelas dos nobres, passando a ter acesso a produtos sofisticados, até aquele momento, inacessíveis ${ }^{49}$.

Embora tais riquezas não possibilitassem aos mercadores a obtenção do prestígio dos nobres, vislumbraram na cópia de costumes, vestimentas e na aquisição de objetos de luxo meios para se aproximar de tão conceituada classe social ${ }^{50}$. Isto pois, tal como observa Werner Sambort, aqueles que nascem em determinada classe e que enriquecem rapidamente tendem a despender suas riquezas em bens de luxo, vez que “(...) a condição de homem natural e tosco não lhe permite disfrutar de outros prazeres além dos materiais" ${ }^{\prime 51}$, sendo tais produtos uma forma de se posicionar junto às classes distinguidas pelo nascimento.

Consequentemente, tendo em vista ser a sociedade medieval altamente hierarquizada, as classes superiores, incomodadas com a ascensão dos mercadores e preocupadas em evitar qualquer espécie de equiparação, uma vez copiadas, tratavam de aderir a novas formas de comportamentos e vestimentas ${ }^{52}$. Consagra-se, assim, ademais

\footnotetext{
49 POLLINI, Denise, Breve história da moda, São Paulo: Editora Claridade, 2007, p. 17. No mesmo sentido, cf. BRAGA, João, Reflexões sobre moda, São Paulo: Editora Anhembi Morumbi, 2011, V. 5, p. $15-16$.

50 AVENTIN, Mercè, La leggi suntuaria in Spagna: stato della questione, in: MUZZARELLI, Maria Giuseppina; CAMPANINI, Antonella (Orgs.), Disciplinare il lusso: la legislazione suntuaria in Itália e in Europa tra medievo ed età moderna, Roma: Carocci, 2003, p. 109.

${ }^{51}$ SOMBART, Werner, Lujo y Capitalismo, [s.1.]: Coleccion Crisis y Soluciones, 1958, p. 111 (tradução livre). De acordo com KANT: "O luxo (luxus) é o excesso no bem viver social, acompanhado do gosto, em uma comunidade (o que é o contrário, por fim, ao bem-estar desta). O mesmo excesso, mas carente de gosto, é a dissipação pública (luxuries)" KANT, Immanuel, Antropología, Madrid: Alianza Editorial, 1991, p. 182 (tradução livre).

${ }^{52}$ Cf. Souza, "Com efeito, a moda é um dos instrumentos mais poderoso de integração e desempenha uma função niveladora importante, ao permitir que o indivíduo se confunda com o grupo e desapareça num todo maior que lhe dá apoio e segurança. E como as modas vigentes são sempre as da classe dominante,
} 
do que se entende por sazonalidade na moda ${ }^{53}$, a busca incessante por símbolos de ostentação, tais como mobiliários requintados, iguarias gastronômicas e tecidos sofisticados.

Em outras palavras, os mercadores e comerciantes tentavam obter o prestígio conferido aos nobres pelo nascimento por meio de suas riquezas e estes, por sua vez, despendiam incalculáveis recursos para se diferenciar e fazer frente aos novos ricos, o que, ao que tudo indica, foi determinante para sua ruína ${ }^{54}$.

Tamanha a magnitude dos excessos desse período que o Estado passou a regular os sinais de riqueza, por meio das denominadas legislações suntuárias (sumptuariae leges $)^{55}$, disciplinando o luxo, gerando uma espécie de "código da aparência" ${ }^{56}$. Essas regulamentações, ademais de outros escopos, buscavam conter os excessos e despesas supérfluas, bem como evitar a equiparação entre classes sociais e de comunidade de crença ${ }^{57}$.

Em outras palavras, configurava-se a intervenção do Estado no campo do simbólico $^{58}$, estabelecendo-se que determinados símbolos e sinais estavam reservados para algumas categorias ${ }^{59}$. Nas palavras de Bourdieu:

O Estado regulamenta o uso dos tecidos e dos ornamentos de ouro, de prata e de seda; fazendo isso, defende a nobreza contra as usurpações dos plebeus, mas ao mesmo tempo estende e reforça a hierarquia dentro da nobreza. É

os grupos mais próximos estão, a cada momento, identificando-se aos imediatamente superiores através da imitação da vestimenta”. SOUZA, O espírito das roupas: a moda no século dezenove, p. 130.

${ }^{53}$ BRAGA, Reflexões sobre moda, p. 16.

${ }^{54}$ Consoante Sombart: “(...) O empobrecimento da nobreza foi a causa determinante do enriquecimento dos credores burgueses”. SOMBART, Lujo y Capitalismo, p. 114 (tradução livre).

${ }^{55}$ As fontes que regulavam essas atividades, dentre outras, podem ser divididas em leis reais, pragmáticas (normas pontuais derivadas do rei), das Cortes (provenientes da atividade parlamentar), municipais (ordens municipais ou concessões e privilégios forais) e documentações eclesiásticas. AVENTIN, La leggi suntuaria in Spagna: stato della questione, p. 110-112.

${ }^{56}$ MUZZARELLI, Maria Giuseppina, Guardaroba medievale: vesti e società dal XIII al XVI secolo, Bologna: Il Mulino, 1999, p. 273. Tais legislações tinham como fim distinguir o nobre do burguês e o cristão do não batizado. AVENTIN, La leggi suntuaria in Spagna: stato della questione, p. 109.

57 A título de exemplo, no tocante a realidade espanhola menciona-se que: “(...) É sabido que estavam presentes na Espanha minorias religiosas e que, até certo ponto, era difícil distinguir os judeus dos mulçumanos ou dos cristãos: somente as diferentes maneiras de se vestir, o penteado e os chapéus usados ou autorizações concedidas". AVENTIN, La leggi suntuaria in Spagna: stato della questione, p. 109 (tradução livre).

${ }^{58}$ BOURDIEU, Pierre, Sobre o Estado: cursos no Collège de France (1989-92), São Paulo: Companhia das Letras, 2012, p. 398.

${ }^{59}$ MUZZARELLI, Guardaroba medievale: vesti e società dal XIII al XVI secolo, p. 272-273. 
uma maneira de controlar a exibição do capital simbólico, que só existe pela exibição; portanto, controlar a exibição do capital simbólico é controlar o capital simbólico ${ }^{60}$.

Notadamente, embora tais leis fossem de difícil aplicação ${ }^{61}$, ao restringir o acesso a determinados bens que não fossem compatíveis com sua respectiva classe, legitimavam-se legislações fortemente discriminatórias, criando-se um sistema das diferenças ${ }^{62}$.

Apenas com a Revolução Francesa foi colocado fim a este sistema de privilégios e de diferença entre grupos sociais, tendo em vista que a burguesia conquistou uma forma de governo participativa ${ }^{63}$. Conforme descreve Gilda de Mello Souza:

\begin{abstract}
Agora as modas podem ser copiadas por todas as classes, pois as leis suntuárias foram abolidas. A posse do dinheiro tornou acessíveis os símbolos da vida ociosa e no amplo e variado espaço urbano - no Passeio Público, no camarote da Ópera, no Cassino, no restaurante de luxo - a arrivista começa a ofuscar a 'dama exemplar' através do luxo dos vestidos. É então que uma nova barreira se interpõe entre as classes, ainda mais difícil de transpor que a antiga, pois já não se apóia na ostentação das riquezas, mas no polimento das maneiras, na composição elaborada dos gestos, enfim no elemento dinâmico da moda. A distinção econômica do luxo cede lugar à distinção estética da elegância ${ }^{64}$.
\end{abstract}

No Brasil, durante o período colonial, uma série de restrições ao luxo, por meio das denominadas "pragmáticas" - normas pontuais editadas pelo rei -, também se fizeram presentes, sobretudo em razão da desconfiança de que o ouro extraído das minas brasileiras não estava sendo devidamente declarados, bem como em face de uma série de episódios de contrabando de metais e pedras preciosas.

\footnotetext{
${ }^{60}$ BOURDIEU, Sobre o Estado: cursos no Collège de France (1989-92), p. 399.

${ }^{61}$ Diversas legislações suntuárias acabaram sendo abandonadas e o nível de riqueza terminou sendo o limite material para o consumo. GRAÇA, João Carlos, Werner Sombart y el hombre económico moderno, Elementos de metapolítica para una civilización europea, n. 38, p. 30-53, p. 45.

${ }^{62}$ A título de exemplo, relembre-se que Eduardo II (1327-1377) tratou de regulamentar em sete capítulos e de forma hierárquica o modo de vestir de toda população, isto é, estabelecendo qual o limite máximo de despesas que poderia ter o servo, o agricultor, o artesão, o comerciante, o senhor, o clero e o cavalheiro. LÜTTENBERG, Thomas, Sempre un passo indrietro rispetto alla moda, in: MUZZARELLI, Maria Giuseppina; CAMPANINI, Antonella (Orgs.), Disciplinare il lusso: la legislazione suntuaria in Itália e in Europa tra medievo ed età moderna, Roma: Carocci, 2003, p. 146.

${ }^{63}$ POLLINI, Breve história da moda, p. 34.

${ }^{64}$ SOUZA, O espírito das roupas: a moda no século dezenove, p. 134.
} 
Nesse sentido, merece referência a pragmática de 1749 estabelecida pelo Reino que, no anverso de seus 31 capítulos, regulava o uso dos adornos, tipos de vestuário, a movelaria e até mesmo o luto ${ }^{65}$.

Sob a justificativa de que se tratava de um "paternal cuidado", D. João V, em discurso relembrava as disposições das legislações suntuárias de seus antecessores com o propósito de manter o Estado rico, a estabilidade de suas forças e o aumento do seu comércio. Tergiversando que "paulatinamente se foram pondo em esquecimento tão proveitosas disposições; e o dano que vão experimentando os meus vassalos, excita o meu paternal cuidado a procurar desenraizá-lo com eficazes remédios" ${ }^{\$ 66}$.

Em outras palavras, procurava advertir seus vassalos sobre os efeitos perniciosos do luxo, estabelecendo, por exemplo, no capítulo $1^{\circ}$, que:

\begin{abstract}
A nenhuma pessoa de qualquer graduação e sexo que seja, passado o tempo abaixo declarado, será licito trazer em arte alguma de seus vestidos, ornatos, enfeites, telas, brocados, fitas, galões, cordões, galancins, passamanes, franjas, cordões, espeguilhas, debruns, borlas, ou qualquer outra sorte de tecido, ou obra em que entrar prata, nem ouro fino, ou falso, nem riço cortado á semelhança de bordado"67.
\end{abstract}

Ainda neste esteio punitivo e impactando na involução da indústria brasileira, menciona-se o Alvará expedido por Dona Maria I, em 1785, determinando o fechamento de quase a totalidade das tecelagens e fiações ${ }^{68}$, tendo em vista que a diminuição da extração do ouro e de diamante teria como causa a falta de obreiros que estariam sendo posicionados no setor têxtil.

Em realidade, ao que parece, a adoção desse e de outros posicionamentos de restrições estava diretamente relacionada ao receio de que o Brasil deixasse de ser

\footnotetext{
${ }^{65}$ Observa Cavalcanti que "a pragmática entrou em detalhes referentes a todos os aspectos, inclusive os ligados às cerimônias fúnebres, regulamentando os espaços a serem utilizados, os tipos de caixão permitidos, o número de tochas e castiçais que poderiam ser acesos e outras minúcias, enfim, que tinham finalidade de coibir o fausto dos enterros das pessoas ricas". CAVALCANTI, Nireu, O Rio de Janeiro Setecentista: a vida e a construção da cidade da invasão francesa até a chegada da corte, Rio de Janeiro: Jorge Zahar Editor, 2004, p. 93.

${ }^{66}$ Ibid., p. 78 e ss.

${ }^{67}$ EDMUNDO, Luiz, O Rio de Janeiro no tempo dos vice-reis (1763-1808), Rio de Janeiro: Imprensa Nacional, 1932, p. 227.

${ }^{68}$ A pena para o descumprimento era a destruição maquinário e a perda da produção. PRADO, Luís André do; BRAGA, João, História da moda no Brasil: das influências às autorreferências, São Paulo: Disal Editora, 2011, p. 38.
} 
consumidor dos produtos portugueses e passasse a ser seu concorrente ${ }^{69}$. Isto pois, a colônia foi estruturada para, ademais de fornecer produtos agrícolas, “(...) funcionar como mercado consumidor da produção fabril de Portugal, sendo permitido que em território brasileiro se instalassem tão-somente manufaturas não concorrenciais"70 .

Segundo o mencionado Alvará, estava autorizado apenas o funcionamento dos teares ou manufaturas destinadas à produção de panos grosseiros e de pouco valor, os quais eram endereçados aos escravos ${ }^{71}$.

A revogação desse documento ocorreu apenas com a vinda de D. João VI e a Corte portuguesa para o Brasil, em 1808, oportunidade em que se consolidou a abertura dos portos às nações amigas, acarretando a aproximação, ainda maior, da cultura e hábitos presentes no estrangeiro, inclusive, em relação à moda.

Em outras palavras, passava-se, ainda que timidamente, de um tempo em que "a colônia portuguesa na América precisava 'de colonos e cultivadores', e não de 'artistas e fabricantes' para um momento de tentativa de fomento e desenvolvimento econômico ${ }^{72}$, conforme se depreende do texto do Alvará de $1^{\circ}$ de abril de 1808 :

Eu o Príncipe Regente. Faço saber aos que o presente alvará virem: que desejando promover e adiantar a riqueza nacional, e sendo um dos mananciais dela as manufaturas e a indústria, que multiplicam e melhoram, e dão valor aos gêneros e produtos da agricultura e das artes, e aumentam a população, dando que fazer a muitos braços e fornecendo meios de subsistência a muitos dos meus vassalos, que por falta deles se entregariam aos vícios da ociosidade ${ }^{73}$.

\footnotetext{
${ }^{69}$ Dentre outras vedações e imposições descritas em sentenças expedidas no período colonial, rememorase aquela que determinava o desmate de algumas árvores brasileiras para que não concorressem com a riqueza do Oriente português, bem como aquelas que criavam impostos abusivos, que fechavam estradas de rodagem, que impediam a exploração de salinas, que determinavam o fechamento dos portos a qualquer estrangeiro, que proibiam o ofício de ourives, que fechavam indústrias nascentes. EDMUNDO, O Rio de Janeiro no tempo dos vice-reis (1763-1808), p. 498.

${ }^{70}$ CAVALCANTI, O Rio de Janeiro Setecentista: a vida e a construção da cidade da invasão francesa até a chegada da corte, p. 78.

71 "Este alvará só cairia após a transferência da Corte portuguesa para o Brasil, em 1808, ano em que foi criado o Tribunal da Real Junta do Comércio, Agricultura, Fábricas e Navegação do Estado do Brasil, que objetivava dinamizar a economia brasileira para, desse modo, poder financiar a manutenção da Corte em seu exílio forçado pela invasão de Portugal por Napoleão Bonaparte". Cf. PRADO; BRAGA, História da moda no Brasil: das influências às autorreferências, p. 38.

72 CAVALCANTI, O Rio de Janeiro Setecentista: a vida e a construção da cidade da invasão francesa até a chegada da corte, p. 79.

${ }^{73}$ GASMAN, Lydinéa, Documentos históricos brasileiros, Rio de Janeiro: Fename, 1976, p. 93.
} 
As legislações suntuárias, que se fizeram presentes no Brasil sob o nome de pragmáticas $^{74}$, e a clara intenção da monarquia portuguesa de reservar a colônia apenas à extração de metais e pedras preciosas, o comércio alimentado pelos negociantes de Portugal e à produção rural $^{75}$, naturalmente, acabaram por tardar a consolidação de uma indústria têxtil brasileira.

Não obstante todos os percalços enfrentados para o desenvolvimento de uma indústria têxtil, nota-se que a produção de algodão, sobretudo em razão da demanda imposta pela revolução industrial, foi determinante para que o país fosse não só provedor de matéria prima para o exterior, mas também para que, ao depois, se consolidasse como um setor economicamente relevante.

\subsubsection{O desenvolvimento do setor têxtil e de confecção brasileiro}

A revolução industrial e o aprimoramento da indústria têxtil no final do século XVIII foram decisivas para o crescimento da lavoura algodoeira brasileira. Até então, o algodão produzido no Brasil no período colonial, de modo geral, era utilizado apenas para a manufatura de tecidos rústicos destinados às sacarias ou para roupas de escravos e de pessoas pobres ${ }^{76}$.

Relembre-se, neste aspecto, que determinações como o anteriormente mencionado alvará de 1785 tinham o claro propósito de destinar toda a mão de obra para a lavoura e minas, tendo em vista que "a 'riqueza real' provinha dos frutos e produtos do solo e não de 'artesões e artífices. Além disso, os 'produtos do solo' constituíam a base do comércio e navegação do Brasil e Portugal"77.

No entanto, os progressos técnicos revelados com a revolução industrial na Inglaterra, transformaram a indústria têxtil, essencialmente produtora de tecidos de lã,

\footnotetext{
${ }^{74}$ Menciona-se que esse expediente foi utilizado por reis como D. Manuel I, D. João III, D. Sebastião I, D. Pedro II e D. João V, cf. SILVA, Camila Borges da, O símbolo indumentário: distinção e prestígio no Rio de Janeiro (1808-1821), Rio de Janeiro: Secretaria Municipal de Cultura, 2010, p. 40.

${ }^{75}$ CAVALCANTI, O Rio de Janeiro Setecentista: a vida e a construção da cidade da invasão francesa até a chegada da corte, p. 79.

${ }^{76}$ HOLANDA, Sérgio Buarque de (Org.), História geral da civilização brasileira: a época colonial, Rio de Janeiro: Bertrand Brasil, 2003, p. 239.

${ }^{77}$ STEIN, Stanley Stein, Origens e evolução da indústria têxtil no Brasil - 1850/1950, Rio de Janeiro: Editora Campus, 1979, p. 20.
} 
em uma indústria mecanizada, cuja matéria prima era o algodão, em especial, aquele advindo do Brasil ${ }^{78}$. Naturalmente, a associação entre maquinários e a abundância dessa fibra, fomentou a que a Inglaterra se destacasse não só em relação a sua técnica de produção, mas em preço.

Em outras palavras, os valores cada vez menores dos tecidos de algodão de origem inglesa puderam concorrer satisfatoriamente em âmbito internacional, com as manufaturas nacionais de tipo artesanal ancorada tecnicamente na tradição medieval ${ }^{79}$.

Como reflexo, a economia brasileira, fundamentalmente rural, fortaleceu-se no idos de 1770 pela exportação da fibra natural de algodão em razão da demanda inglesa, responsável por ampliar “(...) os mercados de consumo para novos tecidos, sustentada pelo sistema de produção em massa para a massa" ${ }^{\$ 0}$.

A lavoura de algodão exigia terras vastas e inúmeros escravos, cuja propriedade, seja do território quanto da mão de obra, concentrava-se nas mãos de poucas famílias ${ }^{81}$. Despontando-se como grandes produtores de algodão o Maranhão e Pernambuco, regiões favorecidas pelo posicionamento geográfico para exportar a matéria prima para a metrópole ${ }^{82}$.

Desta forma, durante o período entre 1780 a 1820, mostrou-se um importante exportador de algodão, relevância comprometida apenas pela produção do algodão proveniente dos Estados Unidos, Egito e Índia ${ }^{83}$.

A vinda da Corte Portuguesa, em 1808, e a revogação do alvará de 1785, bem como a abertura dos portos às nações amigas, representou a mudança na estrutura comercial brasileira. Embora, cumpre observar, a "declarada liberdade fosse restringida pelo tratamento preferencial concedido às importações portuguesas e, imediatamente depois, às inglesas" ${ }^{\prime 4}$.

\footnotetext{
${ }^{78}$ HOLANDA (Org.), História geral da civilização brasileira: a época colonial, p. 239.

${ }^{79}$ Ibid.

${ }^{80} \mathrm{Ibid}$.

${ }^{81}$ STEIN, Origens e evolução da indústria têxtil no Brasil - 1850/1950, p. 20 e 21.

${ }^{82}$ HOLANDA (Org.), História geral da civilização brasileira: a época colonial, p. 240.

${ }^{83}$ STEIN, Origens e evolução da indústria têxtil no Brasil - 1850/1950, p. 57.

${ }^{84}$ Ibid., p. 21.
} 
Décadas depois, a pujança da exportação do café brasileiro deixou à margem o cultivo do açúcar e algodão, oportunidade em que potencializou o tráfico de escravos africanos, tendo seu auge no período entre 1830 e 1850, vez que essa mão de obra se mostrava barata e facilmente substituível. Esse modelo de produção agrícola fundado no trabalho escravo determinou o rumo do desenvolvimento industrial brasileiro.

As tecelagens brasileiras, por sua vez, segundo dados históricos, têm seu surgimento nos idos de 1840, essencialmente para a manufatura de panos rústicos, sendo as demais roupas importadas, vestimentas que, aliás, em nada se coadunavam com o tipo de ruas e clima do país ${ }^{85}$.

Nos idos de 1850, o uso de mão de obra escrava passou a ser abandonada com o surgimento de trabalho assalariado urbano e com a imigração europeia. Note-se que, por outro lado, ainda eram escassos os obreiros livres, tendo em vista a ausência de imigrantes europeus encorajados a vir ao $\mathrm{Brasil}^{86}$, já que ainda vigente escravatura. Ainda, aqueles que por aqui estavam, nem sempre estavam dispostos a desempenhar ofícios associadas aos escravos, como aquele de tecelão ${ }^{87}$.

Em comum, o homem livre assalariado e o escravo tinham a miséria e a falta de habilidade mecânica. A ausência de mão de obra técnica fomentou a que empresários brasileiros buscassem socorro na Inglaterra e, posteriormente, no continente europeu, por operários com habilidades para operar máquinas.

Isto pois, com o surgimento de inventos como a spinnig-jenny ${ }^{88} \mathrm{e}$, posteriormente, a máquina a vapor de James $\mathrm{Watt}^{89}$, considerada por muitos como o

\footnotetext{
${ }^{85}$ Imagina-se que "para um homem, no tempo de Machado de Assis, era banal usar durante o dia casaco e colete de casimira de lã sobre a camisa, a uma temperatura de 40 graus. Igualmente cômico devia ser o fato de as mulheres varrerem com saias longuíssimas o chão sem asseio das ruelas cariocas". DURAND, José Carlos, Moda, luxo e economia, São Paulo: Editora Babel Cultural, 1988, p. 65.

${ }^{86}$ STEIN, Origens e evolução da indústria têxtil no Brasil - 1850/1950, p. 21.

${ }^{87}$ CUNHA, Luiz Antônio, $O$ ensino de ofícios nos primórdios da industrialização, Brasília: Editora Unesp, 2000, p. 3.

${ }^{88}$ A jenny, máquina de fiar criada em 1764 pelo tecelão James Hargreaves, modificou a situação dos trabalhadores ingleses, isto pois, “(...) funcionava manualmente, mas, ao invés de um só fuso, como na roda comum de fiar à mão, tinha dezesseis ou dezoito, acionado por um só operário. Dessa forma, tornou-
} 
"marco zero" da era industrial, modificou-se as relações humanas em todo o mundo, possibilitando a transição do trabalho manual de fiar e de tecer em mecânico e em escala, transformando, em alguma medida, os operários manuais em operadores de máquinas ${ }^{90}$.

Por conseguinte, estava justificada a busca pelo empresariado brasileiro por essa força de trabalho treinada pela revolução industrial ${ }^{91}$. Vigorava a máxima de que "os fabricantes necessitavam dos trabalhadores estrangeiros não apenas por sua habilidade técnica, como também para que orientassem a inexperiente mão de obra local" ${ }^{92}$. Vislumbrando, assim, na mão de obra imigrante, principalmente, artesões, mecânicos e técnicos em fiação e tecelagem de algodão, a possibilidade de desenvolvimento da manufatura nacional ${ }^{93}$.

Neste aspecto, importante relembrar a compreensão do operário em sua concepção atual daquele de outrora,

\begin{abstract}
O operário, no sentido moderno do termo, é compreendido, geralmente, como aquele que trabalha numa fábrica, integrado na divisão social do trabalho com bases capitalistas e que vende sua força de trabalho em troca de um salário. O operário do século XIX era entendido como o povo trabalhador, geralmente executor de uma profissão manual ou que requeresse maior esforço físico, que representava a maioria da população produtiva e sofria, em geral, dos mesmos problemas decorrentes da cartesia, do desemprego, da insegurança diante do futuro, ou seja, do completo desamparo ${ }^{94}$.
\end{abstract}

Com o passar dos anos os operários brasileiros foram ganhando habilidades técnicas e os imigrantes ingleses já não reinavam sozinhos, tendo em vista a chegada,

se possível produzir muito mais fio: se antes um tecelão ocupava sempre três fiandeiras, não contava nunca com fio suficiente e tinha de esperar para ser abastecido, agora havia mais fio doo que o número dos trabalhadores ocupados podia processar". ENGELS, Friedrich, A situação da classe trabalhadora em Inglaterra, São Paulo: Boitempo, 2010, p. 48.

89 “A importância de todas essas máquinas foi duplicada com a máquina a vapor de James Watt, inventada em 1764 e utilizada, a partir de 1785, para acionar as máquinas de fiar”. Ibid., p. 50.

90 COMISSÃO EXECUTIVA TÊXTIL, Indústria Têxtil Algodoeira, Rio de Janeiro: Ministério do Trabalho Indústria e Comércio, 1946, p. 16 e 17. No mesmo sentido: "Com essas invenções, desde então aperfeiçoadas ano a no, decidiu-se nos principais setores da indústria inglesa a vitória do trabalho mecânico sobre o trabalho manual e toda a sua história recente nos revela como os trabalhadores manuais foram sucessivamente deslocados de suas posições pelas máquinas”. ENGELS, A situação da classe trabalhadora em Inglaterra, p. 50.

${ }^{91}$ STEIN, Origens e evolução da indústria têxtil no Brasil - 1850/1950, p. 64.

92 Ibid.

93 Ibid.

${ }^{94}$ LEAL, Maria das Graças de, A arte de ter um ofício: liceu de artes e ofícios da Bahia (1872-1996, Salvador: Fundação Odebrecht; Liceu de Artes e Ofícios da Bahia, 1996, p. 67. 
sobretudo na década de 1890 , de italianos, espanhóis e alemães ${ }^{95}$. Sem dúvidas, foi a chegada dos imigrantes que fortaleceu a indústria têxtil brasileira, fator, inclusive, determinante para que nos dias atuais o Brasil seja um dos poucos países a reunir a maior cadeia completa de produção.

1.2.1.1. A imigração como fator de pujança do setor de confecção: o caso da cidade de São Paulo

Do até aqui apresentado, verifica-se que a consolidação da indústria têxtil e de confecção, em boa medida, pode ser atribuída a chegada dos imigrantes estabelecidos nas mais diversas regiões do Brasil, destacando-se como polos as regiões sul, sudeste e nordeste. Ainda, nota-se que o movimento de imigração e a umbilical relação com o setor segue sendo uma realidade, sobretudo em espaços que se consolidaram pelas confecções de artigos de vestuário como se deu, historicamente, em São Paulo.

O grande valor da indústria têxtil e de confecção em São Paulo pode ser atribuído, dentre outros fatores, a presença, em diversos momentos da história paulista, de alguns grupos sociais, "chamadas etnias comerciais" ${ }^{96}$, dentre os quais, os imigrantes judeus e os coreanos na região do Bom Retiro, os Árabes na região central e os migrantes nordestinos no perímetro do Brás e zona leste ${ }^{97}$. Como se destaca:

\begin{abstract}
São grupos marcados por uma acentuada destinação urbana, que experimentaram uma trajetória de mobilidade socioeconômica muito forte, em geral iniciada pela mascateação, e que, desenvolvida do pequeno ao grande comércio varejista e atacadista, floresceu em alguns setores industriais. No comércio, dedicaram-se em profusão aos armarinhos, roupas prontas e artigos têxteis de modo geral. Na indústria, prosseguiram em setores afins, como o de confecção e o têxtil. O que distingue tais grupos frente à experiência das etnias majoritárias é a forte articulação interna das colônias, alimentada por um sentido de identidade religiosa, familiar ou de conterraneidade capaz de prover uma estrutura de recepção e acolhimento ao imigrante muito operativa ${ }^{98}$.
\end{abstract}

\footnotetext{
${ }^{95}$ STEIN, Origens e evolução da indústria têxtil no Brasil - 1850/1950, p. 65.

96 TRUZZI, Oswaldo Mário Serra; SACOMANO NETO, Mário, Economia e empreendedorismo étnico: balanço histórico da experiência paulista, RAE, v. 47, n. 2, p. 37-48, 2007, p. 43.

${ }^{97}$ KONTIC, Branislav, Inovação e Redes Sociais: a indústria da moda em São Paulo, Faculdade de Filosofia Letras e Ciências Humanas da Universidade de São Paulo, 2007, p. 42.

98 TRUZZI; SACOMANO NETO, Economia e empreendedorismo étnico: balanço histórico da experiência paulista, p. 43.
} 
Na década de 1920, judeus advindos da Rússia, Lituânia e Polônia começaram a se instalar no bairro do Bom Retiro, mas foi nos estertores dos anos 1930 que houve o sensível aumento dessa população, tendo em vista a Segunda Guerra Mundial. Assim,

os novos imigrantes que não tinham ofício iam trabalhar nas oficinas de confecção têxtil montadas durante a década de 20 por judeus que já tinham experiência no ramo. Outros, trabalhavam a prestação, isto é, algum comerciante lhes dava uma quantidade de tecido que deveria ser vendida de casa em casa e paga posteriormente ${ }^{99}$.

Pontua Truzzi que o bairro do Bom Retiro nasceu fabril, do barro de suas várzeas surgiram olarias, e uma indústria de fiação e tecelagem, precocemente em 1884, denotando características de bairro proletário, o que atraiu inúmeros operários ${ }^{100}$.

Como bem observa Timóteo, na década de 1960, com acordo celebrado entre Brasil e Coreia do Sul, verificou-se a chegada de imigrantes coreanos em bairros como Brás e Bom Retiro localizados na Cidade de São Paulo, muitos dos quais começam a trabalhar como vendedores de roupas em lojas mantidas por judeus ${ }^{101}$.

Há indicações de que os judeus, implantados há mais tempo no Bom Retiro em atividades ligadas aos ramos de confecções e à indústria têxtil, passaram também a se interessar pelo emprego de coreanos como costureiros, seja em oficinas, seja em trabalhos domiciliares realizados sob encomenda, ou ainda como vendedores de roupas ${ }^{102}$.

Por outro lado, outros imigrantes coreanos, identificando uma oportunidade de negócio e, portanto, de obtenção de maior lucro, passaram a adquirir suas próprias máquinas de costura, fabricando eles mesmos as peças que colocariam à venda ${ }^{103}$.

\footnotetext{
${ }^{99}$ Informações obtidas junto ao Banco de Dados Folha, "História dos bairros paulistanos: bom retiro". Disponível em: <http://almanaque.folha.uol.com.br/bairros_bom_retiro.htm>. Acesso em: 21 abr. 2019.

${ }^{100}$ TRUZZI, Oswaldo Mário Serra, Etnias em convívio: o bairro do Bom Retiro em São Paulo, Estudos Históricos, v. 27, n. 27, p. 143-166, 2001, p. 145.

101 TIMÓTEO, Gabrielle Louise Soares, Os trabalhadores bolivianos em São Paulo: uma abordagem jurídica, Faculdade de Direito da Universidade de São Paulo, 2011, p. 118. Menciona-se que, de acordo com pesquisa de Buechler, a primeira onda imigratória de coreanos no Brasil teria se dado em 1963, por meio da Associação Brasil-Coreia, com a chegada de 103 pessoas no Porto de Santos. BUECHLER, Simone, Sweating it in the Brazilian garment industry: Korean and Bolivian immigrants and global economic forces in São Paulo, Latin American Perspectives, v. 31, n. 3, p. 99-119, 2004, p. 103.

102 TRUZZI, Etnias em convívio: o bairro do Bom Retiro em São Paulo, p. 151.

${ }^{103}$ TIMÓTEO, Os trabalhadores bolivianos em São Paulo: uma abordagem jurídica, p. 118.
} 
A maior parte dos coreanos aqui chegados jamais havia operado no ramo de confecções antes de sua chegada a São Paulo. Contudo, as atividades de costura eram abraçadas pelos recém-chegados graças à pouca necessidade de capital (muitas fábricas de tecidos concediam prazos dilatados para pagamento das mercadorias retiradas), ao risco pequeno e à possibilidade de empregar toda a família ${ }^{104}$.

Com o tempo os coreanos passaram de funcionários do comércio, até então mantidos por judeus, para donos de lojas e oficinas ${ }^{105}$. Vale observar que o trabalho nessas confecções coreanas era familiar, precário e sem separação clara entre vida doméstica e vida laboral ${ }^{106}$. Isto é, "buscavam concorrer com base em preços baixos, possibilitados por um intenso sweating labour, envolvendo famílias imigradas, largas jornadas de trabalho e utilização de trabalho familiar sem remuneração"107.

Naturalmente, os novos empreendedores passaram a empregar imigrantes também coreanos recém-chegados nas oficinas de costura, cuja competitividade estava relacionada ao baixo custo da mão de obra, os quais, posteriormente, foram gradativamente sendo substituídos por outros imigrantes, mormente bolivianos ${ }^{108}$. Em outros dizeres, “independente da etnia explorada, as confecções do Bom Retiro, desde então, ergueram-se sobre esse tipo de mão de obra, incluindo os empreendimentos daqueles que sofreram tais abusos na fase inicial de imigração" ${ }^{\text {109. }}$.

Ainda, verifica-se do quanto apurado que as confecções paulistas durante variados períodos serviram como porta de entrada para imigrantes. Nesse sentido, relembre-se a crítica de Souchaud, para quem as oficinas de costuras de bairros centrais

\footnotetext{
104 TRUZZI, Etnias em convívio: o bairro do Bom Retiro em São Paulo, p. 151.

105 Menciona-se que os sul coreanos "passaram a comprar as principais lojas do bairro, sobretudo nos anos 80, quando se beneficiaram de uma lei de 1982, que anistiava imigrantes ilegais. Neste período, os judeus começaram a migrar para bairros de caráter mais residencial. Isto aconteceu sobretudo porque as mais novas gerações de origem judaica constituíam-se de profissionais liberais que não quiseram continuar com os negócios da família. Até colégios tradicionais desta comunidade, como o Renascença, foram transferidos para bairros como Higienópolis que concentra hoje cerca de $40 \%$ dos judeus que vivem na cidade". Disponível em: <http://almanaque.folha.uol.com.br/bairros_bom_retiro.htm>. Acesso em: 21 abr. 2019. Salienta Truzzi que "os coreanos começaram a se instalar com lojas por volta de meados da década de 70. A concentração de coreanos na indústria de confecção naturalmente atraiu a colônia para se instalar em um ponto da cidade que já desfrutasse de tradição nesse ramo comercial". Ibid. 106 TIMÓTEO, Os trabalhadores bolivianos em São Paulo: uma abordagem jurídica, p. 118.

${ }^{107}$ KONTIC, Inovação e Redes Sociais: a indústria da moda em São Paulo, p. 46 e 47.

108 A cidade de São Paulo é a que figura com a maior comunidade boliviana do país. TIMÓTEO, Gabrielle Louise Soares, Trabalho em condições análogas à escravidão e a indústria da moda, in: SOUZA, Regina Cirino Alves Ferreira (Org.), Fashion law: direito da moda, São Paulo: D’Plácido, 2019, p. 181.

${ }^{109}$ CHI, Jung Yun, Imigrantes coreanos na formação do polo atacadista de moda feminina de prontaentrega no bairro do Bom retiro, São Paulo, Pós, v. 23, n. 41, p. 90-107, 2016, p. 96.
} 
de São Paulo - dentre outros, Brás, Bom-Retiro e Belém -, geralmente são associadas a lugares de exploração de mão de obra imigrante.

No entanto, pontua a autora, olvida-se que também são locais de inserção social para imigrantes de diversas origens. Isto pois:

\begin{abstract}
a informalidade e flexibilidade da organização das oficinas também facilitam a integração no mercado de trabalho (primeiro trabalho obtido pelo apoio dos membros do grupo familiar ou étnico), a capacitação profissional (grande parte chegam como ajudante, sem conhecimentos na costura), a realização de um projeto migratório (seja no próprio lugar: tornar-se dono de oficina; seja no país de origem: compra de um lote ou casa), para quem, frequentemente indocumentado, sem conhecimento do mercado de trabalho e com um domínio fraco da língua e dos usos da sociedade do país de destino, teria poucas chances de ficar na cidade de São Paulo ${ }^{110}$.
\end{abstract}

Conforme se verificou, a relação entre a imigração e o setor é longínqua e, embora não aquém de problemáticas como aquelas envolvendo a exploração da mão de obra, ainda nos dias atuais, segue sendo motor propulsor para o funcionamento de confecções como se dá em São Paulo.

\title{
1.2.2. O cenário atual do setor têxtil e de confecção no Brasil
}

O Brasil, consoante analisado, tardou a desenvolver o setor têxtil, sendo considerado sua efetiva implantação na segunda metade do século XIX, sobretudo em razão da suspensão das tarifas alfandegárias de maquinário importado, possibilitando a entrada de equipamentos mais modernos para tecer e fiar.

Não obstante todos os entraves encontrados, sejam eles relacionados às questões econômicas, pela mão de obra pouco qualificada ou pela informalidade ainda existente no país, verifica-se que a indústria têxtil e de confecção se firmou como relevante para o cenário econômico nacional. Inclusive revelando nos dias atuais grandes grupos de moda responsáveis pela aquisição de marcas icônicas, como a

\footnotetext{
110 SOUCHAUD, Sylvain, A confecção: nicho étnico ou nicho econômico para a imigração latinoamericana em São Paulo?, in: BAENINGER, Rosana (Org.), Imigração Boliviana no Brasil, Campinas: Núcleo de Estudos de População (Nepo) - Unicamp, 2012, p. 80.
} 
companhia InBrands S.A, detentora das marcas Ellus, Richards, VR, Salinas, Herchcovitch; Alexandre e Bob Store ${ }^{111}$.

Consoante dados da Associação Brasileira da Indústria Têxtil (ABIT), formulados entre os anos 2017 e 2018, a indústria, com quase 200 anos no país, ostenta a maior cadeia produtiva completa do Ocidente, sendo responsável pela produção de fibras, tendo fiações, tecelagens, beneficiadoras, confecções e forte varejo de vestuário, faturando US\$ 51,58 bilhões $^{112}$.

Ao todo, ainda segundo dados da Associação, o setor reúne 25,2 mil empresas formais com mais de cinco funcionários em todo o país, destacando-se como o quarto maior produtor de denim e de malhas do mundo. O segmento têxtil é responsável pela produção de 1,2 milhão de toneladas e o setor de confecção por 8,9 bilhões de peças (vestuário, meias, acessórios, cama, mesa e banho) ${ }^{113}$.

Ainda, é o segundo maior empregador da indústria de transformação, ficando atrás apenas de alimentos e bebidas juntos, sendo responsável por empregar diretamente 1,5 milhão de pessoas, dos quais $75 \%$ são de mão de obra feminina, e é o segundo maior gerador do primeiro emprego ${ }^{114}$. Em valores de produção, segundo o

\footnotetext{
111 Destaca Cury que "o objetivo do grupo mencionado é justamente a realização de aquisições, desenvolvimento e gestão profissionalizada e eficiente de determinadas marcas reconhecidas de alto padrão e que tenham potencial de alta rentabilidade, inovação, ampla distribuição e visibilidade no Brasil. Além disso, o grupo consolidou marcas estratégicas de conteúdo de moda, incluindo a realização dos dois maiores eventos de moda brasileiros (São Paulo Fashion Week e o Fashion Rio)". CURY, Maria Fernanda C. A. R, Mecanismos de transferência da identidade criativa da marca em aquisição, in: ROSINA, Mônica Steffen Guise; CURY, Maria Fernanda C. A. R (Orgs.), Fashion law: direito da moda no Brasil, São Paulo: Revista dos Tribunais, 2018, p. 105-127. Mencionam-se ainda como grupos relevantes de moda a AMC Têxtil LTDA. detentora das marcas Colcci, Carmelitas, Sommer, Fórum, Forum Tufi Duek, Tufi Duek, Triton e possui licença sobre a marca Coca-Cola Jeans, bem como o grupo Soma que abarca as marcas A.Brand, Animale, Fábula, Farm, Foxton, FYI e Más.

112 Dados gerais do setor referentes a 2018, com atualização em 2019. Disponível em: <https://www.abit.org.br/cont/perfil-do-setor>. Acesso em: 13 dez. 2019.

${ }^{113}$ Disponível em: <https://www.abit.org.br/cont/perfil-do-setor>. Acesso em: 13 dez. 2019.

${ }^{114}$ Disponível em: <https://www.abit.org.br/cont/perfil-do-setor>. Acesso em: 13 dez. 2019. Em setembro de 2017 foi publicado relatório encomendado pela European Commission and the Executive Agency for Small and Medium-sized Enterprises (EASME) sobre os mercados de exportação de têxteis abarcando o Brasil, Japão Coreia do Sul e Estados Unidos da América, com escora de conhecer as oportunidades têxteis fora da União Europeia. A presença do Brasil em tal relatório sinaliza os olhares atentos para esse destacado setor nacional. Disponível em: <https://ec.europa.eu/growth/content/country-reports-technicaltextiles-brazil-japan-south-korea-and-usa_en>. Acesso em 13 dez. 2018.
} 
IEMI, o Brasil chegou a aproximadamente R \$ 144,9 bilhões e na exportação, embarcou cerca de US\$137,7 milhões ${ }^{115}$.

A demonstrar a complexidade do setor, verifica-se que esse importante segmento envolve uma série de etapas na cadeia produtiva, uma pluralidade de modelos de negócios, inúmeros profissionais com distintas habilidades e fazeres, como produtores rurais, engenheiros têxteis, designers, modelos, digital influencers, profissionais da área comercial e logística, administradores e gestores.

Em linhas gerais, engloba a transformação da matéria prima (natural, artificial ou sintética em fios); o beneficiamento das fibras e fios (cor, elasticidade e textura); a tecelagem (transformação dos fios em tecido) - a qual também demanda beneficiamento (tingimento, estamparia e impermeabilização) - e, por fim, a confecção do tecido em roupas, as quais incorporarão botões, zíperes, fivelas, bordados, etiquetas, entre outros ${ }^{116}$.

Esse processo de produção está sujeito a uma série de variáveis, como em relação a estratégia de negócio adotada, isto é, exemplificativamente: se a empresa seguirá uma produção de moda tradicional, ou seja, de coleções periódicas e pautadas nas estações do ano; um modelo slow fashion, em linhas gerais, de produção consciente e sustentável ou, ainda, um modelo fast fashion de confecção em massa com inúmeros lançamentos e coleções ao longo do ano.

A esse emaranhado de filigranas pode ser adicionada a escolha empresarial por desenvolver internamente toda a produção fabril ou a terceirização de parte ou da integralidade da produção têxtil e de confecção. Circunstâncias que impactam não só no processo produtivo, mas, essencialmente, nos riscos jurídicos que permeiam a atividade.

A título de exemplo, uma empresa que atua na produção de denim certamente está mais sensível a questões ambientais do que aquela que atua no varejo de moda e que terceiriza sua produção. Por outro lado, a segunda, fatalmente, está mais

\footnotetext{
115 Disponível em: <https://www.iemi.com.br/cerca-de-11-milhao-de-funcionarios-na-industria-demoda/>. Acesso em: 13 dez. 2019.

${ }^{116}$ Essas etapas são descritas por: DURAND, Moda, luxo e economia, p. 50.
} 
vulnerável quanto às questões relacionadas à propriedade intelectual, bem como no que toca as relações trabalhistas e a exploração do trabalho humano. No entanto, ambas, por motivos diversos, estão igualmente expostas aos crimes tributários e de crime de corrupção ao possivelmente se relacionar com o poder público.

Desta forma, nota-se que a criminalidade, seja ela clássica ou dita econômica e empresarial, ladeia a atividade das empresas de moda, mas o risco de ocorrência será de maior ou de menor escala consoante o tipo de negócio praticado, os valores e a missão da empresa e a tomada de postura empresarial para mitigá-los.

Assim, na sequência, traçar-se-á um panorama sobre alguns crimes recorrentes na indústria da moda e que podem, ademais de outras consequências, gerar desgaste para a imagem empresarial. A saber: os crimes contra a propriedade imaterial; o trabalho análogo ao de escravo nas confecções brasileiras; o crime de assédio sexual; a proposta de criminalização do assédio moral; os crimes ambientais e o crime de lavagem de dinheiro no setor de joias e luxo. 


\section{CONCLUSÃO}

1. O fashion law, direito aplicado à indústria da moda, passou a ser descortinado com maior afinco na última década, sobretudo com o protagonismo das pesquisas e análises de casos emblemáticos, sobretudo em matéria de propriedade intelectual, pela autora norteamericana Susan Scafidi.

2. Alguns trabalhos anteriores podem ser verificados, tais como o de Belhumeur e Bertrand, ambos também sob uma perspectiva da moda com a propriedade intelectual. No entanto, foi por meio da designação de um nome para esse fenômeno que a temática ganhou projeção e capilaridade, sendo nos dias atuais, por motivos diversos, objeto de estudo em diversos países.

3. O etiquetamento levado a efeito com a expressão "fashion law" possibilitou o florescer de vozes em variados continentes no sentido de que essa indústria reúne peculiaridades que merecem um olhar diferenciado do jurista.

4. É verdade que o direito da moda flerta com os mais diversos ramos jurídicos, dentre outros, o direito dos contratos, o direito do trabalho, o direito ambiental e o direito penal. Por outro lado, as características da indústria em foco e os problemas dali decorrentes despontam a necessidade de um aperfeiçoamento jurídico compatível com suas complexidades e particularidades. E, no caminho futuro, ao que tudo indica, do reconhecimento de autonomia do fashion law como campo de estudo jurídico.

5. Dentre outras especificidades, mencionam-se as relações profissionais estabelecidas entre os mais diversos atores que atuam no setor, como modelos, estilistas, fotógrafos e digital influencers; as coleções por temporada; o complexo processo produtivo do setor têxtil e de confecção; o exponencial número de produtos contrafeitos como bolsas, roupas, óculos e sapatos e as medidas adotadas para combate à pirataria e às falsificações; o uso de peles e testes em animais; e a expansão de grandes companhias reunindo em um só grupo marcas icônicas de moda e luxo.

6. Ainda, a diferenciar a moda de outros setores da economia e a necessária apuração particular desse segmento, nota-se a exponencial importância dada aos valores 
intangíveis, dentre eles, a imagem corporativa e a marca. Isto é, fatores fundamentais para competividade, permanência e perenidade do negócio nesse concorrido mercado.

7. Verifica-se, neste contexto, que a grande oferta de produtos similares, fenômeno que se justifica, inclusive, pela massificação e pela necessidade de produção célere, inibindo a criatividade e a maior diversidade daquilo que é oferecido ao mercado, provocou a maior atribuição de valor aos aspectos intangíveis. Isto é, em um universo de abundância de mercadorias, as quais pouco ou nada se diferenciam, cada vez mais influi na decisão do consumidor o fator incorpóreo embutido em determinado produto.

8. Acresce-se a isso o fato que nos últimos anos formou-se um novo contexto social, composto por consumidores questionadores e sensíveis a questões como ética, diversidade e responsabilidade socioambiental. Assim, os valores imateriais que acompanham um produto de moda ganham maior relevância e, igualmente, as marcas que se atentam a essas questões fomentam seu ativo intangível tonando-se mais atrativas e competitivas.

9. A contrario sensu as empresas que descuidam da proteção de seu patrimônio incorpóreo estão mais suscetíveis a serem impactadas por danos reputacionais, nem sempre corrigíveis. Realidade essa que ficou ainda mais exposta com o advento da internet e, sobretudo, das redes sociais que contribuíram para desvelar as informalidades praticadas pela indústria, vale dizer, problemas presentes desde a sua formação, mas agora escancarados, não só pela mídia, mas pelos compradores investigativos, sleuthy shoppers, que julgam as empresas como amiga ou inimiga de suas causas.

10. Em um mundo globalizado e de amplo acesso à informação, a imagem empresarial tornou-se significativo fator de diferenciação e, diuturnamente, atribui-se maior valor a reputação corporativa. Desta forma, a reputação corporativa figura como um importante princípio para o criminal fashion law.

11. As empresas de moda que vigilam pela integridade e transparência da organização, além de evitar riscos na cadeia de fornecimento como aqueles relativos as 
violações a direitos humanos, evitando-se responsabilidades criminais, impactos financeiros e sociais, podem fomentar políticas corporativas pró-ativas, tal como a responsabilidade socioambiental, recurso a ser explorado positivamente e não mais identificado como um centro de custo.

12. Desta forma, o direito, que ao longo dos anos foi visto pela indústria da moda como área periférica e, portanto, quase sempre acionado apenas para a resolução de conflitos já postos, passou a ganhar maior importância, sobretudo no sentido de prevenção de riscos jurídicos.

13. Neste esteio, extrai-se como uma faceta do direito da moda o criminal fashion law, ou seja, o direito penal aplicado à moda. Isto pois, ademais de algumas questões penais serem bastante aguçadas nessa indústria, dentre eles, os crimes contra a propriedade imaterial; o trabalho análogo ao de escravo; o assédio sexual; os crimes ambientais; e o crime de lavagem de dinheiro, verifica-se que o delito gera, além de consequências estigmatizantes ensejadas pela sanção, um dano reputacional à empresa.

14. Isto é, ademais das citadas infrações serem significativamente perceptíveis na indústria em comento, o que por si só, já justificaria um olhar de forma destacada, verifica-se que as consequências em razão de suas ocorrências proporcionam impactos suficientemente negativos a demandar assunção de peculiares posturas preventivas para a evitação.

15. As crises corporativas podem parecer surgir de forma sub-reptícia, no entanto, problemas reais, ainda que aparentemente isolados, sinalizam-se como alertas da iminência de um colapso ou escândalo. Particularmente na indústria da moda, então, diversos são os sinais que vem sendo dados para que suas empresas passem a se preocupar com entorno como um todo e não só com a fabricação de produto.

16. Verificou-se na presente análise que um desses alertas diz respeito à observância das relações éticas laborais na cadeia de fornecimento, dado sobretudo a ocorrência de escândalos envolvendo confecções a serviço de grandes marcas de moda. Exposição essa ainda mais agravada dada a visibilidade das empresas desse setor se comparadas com outros segmentos, como o da construção civil ou do agronegócio, 
visibilidade que levou a indústria da moda a ser interpretada no diálogo social como uma das grandes responsável pela exploração do trabalho humano, mormente o trabalho análogo ao de escravo.

17. Vivencia-se, assim, o contágio intrasetorial, ou seja, empresas flagradas utilizando esse tipo de mão de obra e que padeceram com os impactos negativos dessas condutas, como aqueles de ordem financeira, de imagem e de estigmatização, estão servindo como instrumento para a identificação da necessidade de mudanças e a consequente reformulação de posturas informais arraigadas.

18. Ainda como sinal a ser interpretado e a servir de catalisador para a promoção de mudança na cultura negativa de informalidade instalada desde os tempos coloniais, nota-se um emblemático movimento de intensificação de medidas pela transparência, pelas certificações e pela responsabilidade socioambiental, tidos constantemente como verdadeiros critérios para perenidade do negócio, demandando das corporações a assunção de uma nova postura, isto é, pautada em valores éticos, identificação de riscos, sobretudo aqueles de natureza penal, monitoramento e claridade nas relações estabelecidas ao longo da cadeia de produção.

19. Desta forma, observar os gatilhos de crise são fundamentais para a criação de estratégias preventivas para a evitação de delitos. O conhecimento dos riscos, das vulnerabilidades e a criação de planejamento estratégico permitem que em uma situação de anormalidade, se não evitável, a empresa possa conduzi-la e não ser conduzida por ela, ou seja, ter que lidar de assoberbo com o imprevisto e, por vezes, incorrer na impossibilidade de não reversão do dano negativo.

20. Vê-se, assim, no criminal compliance para a indústria da moda um instrumento fundamental para evitação de riscos penais nas empresas que atuam nesse segmento. Isto é, em que pese não se tratar de um setor regulado, em razão da superexposição das marcas, implementá-lo significa antecipar-se a uma tendência que vem se firmando, sobretudo, como já destacado, pelos movimentos pela transparência na indústria. 
21. Por meio do código de conduta e políticas, transmite-se a cultura de integridade da organização não só internamente, mas aos fornecedores e outras partes interessadas. Ainda, com o monitoramento pode-se evitar que violações criminais ocorram, bem como mitigar falhas identificadas e corrigir gargalos, afastando-se, consequentemente, danos reputacionais.

22. Do mesmo modo, comunica-se aos stakeholders os esforços empreendidos e os resultados alcançados, gerando a percepção de que determinada organização possui uma consciência de integridade e responsabilidade com o entorno social, reforçando, consequentemente, a reputação corporativa positiva, capital simbólico igualmente importante aos ativos tangíveis, bem como fator que pode ser um diferencial para o enfrentamento de uma crise.

23. É verdade a informalidade acompanha a indústria da moda desde o seu embrionário surgimento, no entanto, como visto, caminha-se em um movimento de correção dos equívocos do passado, o que, paulatinamente, vem se espraiando como uma tendência, mas que em pouco tempo será realidade, vez que um caminho sem volta.

24. Trata-se, por outro lado, como dito, de uma mudança de cultura e, portanto, a ser atingida a passos lentos, mas que, pela dor sentida, vem dando demonstrativos de que a sobrevivência de um negócio de moda demandará uma postura proativa corporativa preocupada com o todo e que tenha na prevenção de ilícitos, mormente penais, um pilar rígido e necessário. 


\section{BIBLIOGRAFIA}

ABREU, Lígia Carvalho. Moda e direitos humanos. In: BELLO KNOLL, Susy Inés; ECHEVERRÍA, Pamela; MENDES, Andre Mendes (Orgs.). Moda, luxo e direito. Buenos Aires: Editoral Albremática, 2016, p. 14-21.

Os princípios do direito da moda e sua relevância na construção e autonomia de uma nova disciplina jurídica. In: ABREU, Lígia Carvalho; COUTINHO, Francisco Pereira (Orgs.). Direito da moda: vol I. Lisboa: CEDIS, 2019, p. 11-32.

ALEXANDER, Cindy R. On the nature of the reputational penalty for corporate crime: Evidence. Journal of Law and Economics, v. 42, n. 2, p. 489-526, 1999.

ALVES, Elvisney Aparecido. Desafios de governança da responsabilidade social na cadeia produtiva: o caso da indústria calçadista de franca. REAd - Revista Eletrônica de Administração, v. 11, n. 5, p. 1-14, 2005.

AMAESHI, Kenneth; NNODIM, Paul; OSUJI, Onyeka. Corporate social responsibility, entrepreneurship, and innovation. London-New York: Routledge Studies in Business Ethics, 2013.

APARICIO TOVAR, Joaquín; VALDÉS DE LA VEGA, Berta. Sobre el concepto de responsabilidad social de las empresas: un análisis europeo comparado. Cuadernos de Relaciones Laborales, v. 27, n. 1, p. 53-75, 2009.

ARGENTI, Paul A. Comunicação empresarial: a construção da identidade, imagem e reputação. Trad. Paulo Roberto de MIGUEL. Rio de Janeiro: Elsevier, 2014.

ARTESE, Gustavo. Compliance digital: proteção de dados pessoais. In: CARVALHO, André Castro et al (Orgs.). Manual de compliance. Rio de Janeiro: Forense, 2019, p. $495-519$.

ASCARELLI, Tulio. Teoría de la concurrencia y de los bienes inmateriales. Trad. 
Evelio VERDERA; Luis SUÁREZ- LLANOS. Barcelona: BOSCH, Casa Editorial, 1970.

AVELAR, Suzana; VICENTINI, Claudia Garcia. Moda contemporânea: algumas considerações iniciais sobre moda, cultura digital e indústria 4.0. In: Fashion law: direito da moda. São Paulo: D’Plácido, 2019, p. 347-354.

AVENTIN, Mercè. La leggi suntuaria in Spagna: stato della questione. In: MUZZARELLI, Maria Giuseppina; CAMPANINI, Antonella (Orgs.). Disciplinare il lusso: la legislazione suntuaria in Itália e in Europa tra medievo ed età moderna. Roma: Carocci, 2003, p. 109-120.

BACIGALUPO, Enrique. Compliance y derecho penal. Navarra: Editorial Aranzandi, 2011.

BADARÓ, Gustavo Henrique; BOTTINI, Pierpaolo Cruz. Lavagem de dinheiro: aspectos penais e processuais penais. Comentários à Lei 9.613/1998, com as alterações da Lei 12.683/2012. São Paulo: Revista dos Tribunais, 2012.

BADARÓ, Jennifer Falk. Dolo no crime de lavagem de dinheiro. Belo Horizonte: D’Plácido, 2018.

BARBOSA, Julianna Nunes Targino. A culpabilidade na responsabilidade penal da pessoa jurídica. Universidade de São Paulo, 2014.

BARRÈRE, Christian; DELABRUYÈRE, Sophie. Intellectual property rights on creativity and heritage: The case of the fashion industry. European Journal of Law and Economics, v. 32, n. 3, p. 305-339, 2011.

BARTLEY, Tim. Corporate accountability and the privatization of labor standards: struggles over codes of conduct in the apparel industry. Polities and the Corporation Research in Political Sociology, v. 14, p. 211-244, 2005.

BAUDRILLARD, Jean. A sociedade de consumo. Rio de Janeiro: Elfos Editora, 1995. 
BELHUMEUR, Jeanne. Droit international de la mode. Padova: Canova Treviso, 2000.

BELLEGO, Christophe. Reshoring: a multifaceted decision involving much more than just labour costs. Direction générale de la competitivité de l'industrie et des services, n. 30, p. 1-4, 2014.

BENDIXEN, Michael; ABRATT, Russell. Corporate identity, ethics and reputation in supplier-buyer relationships. Journal of Business Ethics, v. 76, n. 1, p. 69-82, 2007. BERTOCCELLI, Rodrigo de Pinho. Compliance. In: CARVALHO, André Castro et al (Orgs.). Manual de compliance. Rio de Janeiro: Forense, 2019, p. 37-54.

BERTRAND, André. Le droit d'auteur et les droits voisins. Paris: Dalloz, 1999. BITENCOURT, Cezar Roberto. Tratado de direito penal: parte especial - crimes contra a pessoa. São Paulo: Saraiva, 2016.

BLANCO CORDEIRO, Isidoro. La prevención del blanqueo de capitales. In: NIETO MARTÍN, Adan et al (Orgs.). Manual de cumplimiento penal en la empresa. Valencia: GARCÍA MORENO, Beatriz, 2015.

BLUMENBERG, Axel-Dirk; GÁRCIA-MORENO, Beatriz. Retos prácticos de la implementación de programas de cumplimento normativo. In: HORTAL IBARRA, Juan Carlos; VALIENTE IVAÑEZ, Vicente (Orgs.). Responsabilidad de la empresa y compliance: programas de prevención, detección y reacción penal. MontevideoBuenos Aires: BdeF, 2014, p. 273-300.

BONATTI, Gisele Alves. A logística reversa como instrumento da redução dos impactos ambientais da indústria da moda. In: SOUZA, Regina Cirino Alves Ferreira (Org.). Fashion law: direito da moda. Belo Horizonte: D’Plácido, 2019, p. 189-212.

BOURDIEU, Pierre. Razões práticas: sobre a teoria da ação. Campinas: Papirus Editora, 2008. 
Sobre o Estado: cursos no Collège de France (1989-92). Trad. Rosa Freire AGUIAR. São Paulo: Companhia das Letras, 2012.

BRAGA, João. Reflexões sobre moda. São Paulo: Editora Anhembi Morumbi, 2011.

BRISCOE, Dennis R; SCHULER, Randall S. International human resource management: policy and practice for the global enterprise. New York: Routledge, 2004.

BROMLEY, Dennis B. Relationships between personal and corporate reputation. European Journal of Marketing, v. 35, n. 3/4, p. 316-334, 2001.

BRUNO, Flavio da Silveira. A quarta revolução industrial do setor têxtil e de confecção: a visão de futuro para 2030. São Paulo: Estação das Letras e Cores, 2016.

BUECHLER, Simone. Sweating it in the Brazilian garment industry: Korean and Bolivian immigrants and global economic forces in São Paulo. Latin American Perspectives, v. 31, n. 3, p. 99-119, 2004.

BURBIDGE, Rosie. European fashion law. Cheltenham: Edward Elgar Publishing, 2019.

BUSATO, Paulo César. O que não se diz sobre o criminal compliance. In: PALMA, Maria Fernanda; DIAS, Augusto Silva; MENDES, Paulo de Sousa (Orgs.). Estudos sobre law enforcement, compliance e direito penal. Coimbra: Almedina, 2018, p. 2155.

CALOVI, Francesca; VETTORI, Barbara; YU, Jin. I falsi di moda: le vunerabilità del mercato italiano della moda alla contraffazione. Milano: Franco Angeli, 2008.

CALVO GAllegO, Francisco Javier. Códigos éticos y derechos de los trabajadores. Albacete: Editorial Bomarzo, 2008.

CAMPBELL, Greg. Blood Diamonds: tracing the deadly path of the world's most 
precious stones. Cambridge: Basic Books, 2004.

CAMPO, Antonella di. Innovación y tecnología en la moda: análisis desde la perspectiva del fashion law. In: SOUZA, Regina Cirino Alves Ferreira (Org.). Fashion law: direito da moda. São Paulo: D’Plácido, 2019, p. 355-373.

CARDIA, Wesley. Crise de imagem: os conceitos e os meios necessários para compreender os elementos que levam às crises e como administrá-las. Rio de Janeiro: Mauad X, 2015.

CARO CORIA, Dino Carlos. Derechos humanos, compliance e industrias extractivas en América Latina. In: DEMETRIO CRESPO, Eduardo; NIETO MARTÍN, Adan (Orgs.). Derecho penal económico y derechos humanos. Valencia: Tirant lo blanch, 2018, p. $365-389$.

CARVAJAL GÓMEZ-CANO, Fernando; PÉREZ GARCÍA, Esther. Responsabilidad social corporativa en el sector de la moda y el lujo. In: ORTEGA BURGOS, Enrique (Org.). Fashion law (derecho de la moda). Pamplona: Aranzadi, 2018, p. 445-465.

CARVALHAL, André. Moda com propósito: manifesto pela grande virada. São Paulo: Paralela, 2016.

CAVALCANTI, Nireu. O Rio de Janeiro Setecentista: a vida e a construção da cidade da invasão francesa até a chegada da corte. Rio de Janeiro: Jorge Zahar Editor, 2004.

CENTRO DE DIREITOS HUMANOS E EMPRESAS. Reflexões sobre o Decreto 9571/2018 que estabelece Diretrizes Nacionais sobre empresas e Direitos Humanos. Caderno de Pesquisa Home, v. 1, n. 7, p. 1-18, 2018.

CHAVES, Antônio. As obras de arte aplicada no direito brasileiro. Revista de Informação legislativa, v. 21, n. 83, p. 401-410, 1984.

CHI, Jung Yun. Imigrantes coreanos na formação do polo atacadista de moda feminina 
de pronta-entrega no bairro do Bom retiro, São Paulo. Pós, v. 23, n. 41, p. 90-107, 2016.

CHUN, Rosa. Corporate reputation: Meaning and measurement. International Journal of Management Reviews, v. 7, n. 2, p. 91-109, 2005.

CIETTA, Enrico. A economia da moda: porque hoje um bom modelo de negócios vale mais do que uma boa coleção. São Paulo: Estação das Letras e Cores, 2017.

COMISSÃO EXECUTIVA TÊXTIL. Indústria Têxtil Algodoeira. Rio de Janeiro: Ministério do Trabalho Indústria e Comércio, 1946.

COSTA, Patricia Trindade Maranhão. Fighting forced labour: the example of brazil. International Labour Office, p. 1-122, 2009.

COSTA, Helena Regina Lobo da. Proteção penal ambiental: viabilidade, efetividade, tutela por outros ramos do direito. São Paulo: Saraiva, 2010.

CUNHA, Luiz Antônio. O ensino de ofícios nos primórdios da industrialização. Brasília: Editora Unesp, 2000.

CURY, Maria Fernanda C. A. R. Fashion law: a proteção à propriedade intelectual na indústria criativa da moda. Curitiba: Brazil Publishing, 2019.

Mecanismos de transferência da identidade criativa da marca em aquisição. In: ROSINA, Mônica Steffen Guise; CURY, Maria Fernanda C. A. R (Orgs.). Fashion law: direito da moda no Brasil. São Paulo: Revista dos Tribunais, 2018, p. 105-127.

DIAS, Silvia Eleni Vechim; CARLONI, Alessandro Ramos; MELO JÚNIOR, Tadeu Artur de. Resíduos e efluentes gerados pelos curtumes de franca: uma análise considerando as novas exigências internacionais. Revista Eletrônica "Diálogos Acadêmicos", v. 7, n. 2, p. 49-66, 2014.

DURAND, José Carlos. Moda, luxo e economia. São Paulo: Editora Babel Cultural, 
1988.

EDMUNDO, Luiz. O Rio de Janeiro no tempo dos vice-reis (1763-1808). Rio de Janeiro: Imprensa Nacional, 1932.

ENGELS, Friedrich. A situação da classe trabalhadora em Inglaterra. Trad. B.A SCHUMANN. São Paulo: Boitempo, 2010.

FASSON LLOSA, Annalucia. Moda sostenible o sustentable. In: SOUZA, Regina Cirino Alves Ferreira (Org.). Fashion law: direito da moda2. São Paulo: D’Plácido, 2019, p. 213-224.

FITTANTE, Aldo. Brand, industrial design e made Italy: la tutela giuridica: lezioni de diritto della proprietà industriale. Milano: Giuffrè Editore, 2015.

FOMBRUN, Charles. Reputation: realizing value from the corporate image. Massachusetts: Harvard Business School Press, 2018.

FORCADA BARONA, Ignacio. Derecho internacional, responsabilidad social corporativa y derechos humanos. In: DEMETRIO CRESPO, Eduardo; NIETO MARTÍN, Adan (Orgs.). Derecho penal económico y derechos humanos. Valencia: Tirant lo blanch, 2018, p. 53-85.

FORNI, João José. Gestão de crises e comunicação: o que gestores e profissionais de comunicação precisam saber para enfrentar crises corporativas. São Paulo: Atlas, 2017.

GAMA CERQUEIRA, João da. Tratado da propriedade industrial - volume 1. São Paulo: Revista dos Tribunais, 1982.

GARCÍA CAVERO, Percy. Compliance y lavado de activos. In: CALCINA HANCCO, Aldo (Org.). Responsabilidad de la empresa y compliance. Santiago-Chile: Ediciones Olejnik, 2018. 
GARCÍA CAVERO, Percy. Criminal compliance: en especial compliance anticorrupción y antilavado de activos. Lima: Instituto Pacífico, 2017.

GASMAN, Lydinéa. Documentos históricos brasileiros. Rio de Janeiro: Fename, 1976.

GIOVANINI, Wagner. Compliance a excelência na prática. São Paulo: [s.n.], 2014.

GODOY, Mariana Hamar Valverde; COSTA, Michelle Hamuche. Direito de imagem e sua evolução com o mercado da moda no Brasil. In: SOUZA, Regina Cirino Alves Ferreira (Org.). Fashion law: direito da moda. São Paulo: D’Plácido, 2019, p. 151163.

GOMES, Mariângela Gama de Magalhães. Teoria geral da parte especial do direito penal. São Paulo: Atlas, 2014.

GÓMEZ MARTÍN, Víctor. Compliance y derechos de los trabajadores. In: HORTAL IBARRA, Juan Carlos; IVAÑEZ VALIENTE, Vicente (Orgs.). Responsabilidad de la empresa y compliance. Montevideo-Buenos Aires: BdeF, 2014, p. 421-458.

Penas para las personas jurídicas: ¿ovejas con piel de lobo? In: CALCINA HANCCO, Aldo (Org.). Responsabilidad penal de las empresas y compliance program. Santiago-Chile: Ediciones Olejnik, 2018, p. 17-61.

GÓMEZ RIVERO, Maria del Carmen. Los delitos contra la propiedade intelectual e industrial: la tutela penal de los derechos sobre bienes inmateriales. Valencia: Tirant lo blanch, 2012.

GÓMEZ TOMILLO, Manuel. Compliance penal y política legislativa: el deber personal y empresarial de evitar la comisión de ilícitos en el seno de las personas jurídicas. Valencia: Tirant lo blanch, 2016.

GONZÁLEZ FRANCO, J.A; SCHEMMEL, A.; BLUMENBERG, A. La función del penalista en la confección, implementación y evaluación de los progrmas de 
cumplimento. In: ARROYO ZAPATERO, Luis; NIETO MARTÍN, Adán (Orgs.). El derecho penal económico en la era compliance. Valencia: Tirant lo Blanch, 2013.

GRAÇA, João Carlos. Werner Sombart y el hombre económico moderno. Elementos de metapolítica para una civilización europea, n. 38, p. 30-53.

GRIESER, Aaron. Defining the outer limits of global compliance programs: emerging legal \& eeputational liability in corporate supply chains much has been written on corporate codes of conduct in the last decade as such codes have risen to an important. Oregon Review of int'l law, v. 10, p. 285-325, 2008.

GRUMBACH, Didier. History of international fashion. Massachusetts: Interlink Books, 2014.

HENNINGER, Claudia E.; ALEVIZOU, Panayiota J.; OATES, Caroline J. What is sustainable fashion? Journal of Fashion Marketing and Management, v. 20, n. 4, p. $400-417,2016$.

HERMAN, Andrew. Reassessing the role of supplier codes of conduct: closing the gap between aspirations and reality. Virginia Journal of International Law, v. 52, n. 2, p. $445-481,2012$.

HERZECA, Lois F.; HOGAN, Howard S. Fashion law and business: brands \& retailers. New York: Practising Law Institute, 2013.

HOLANDA, Sérgio Buarque de (Org.). História geral da civilização brasileira: a época colonial. Rio de Janeiro: Bertrand Brasil, 2003.

HONNETH, Axel. Observações sobre a reificação. Civitas-Revista de Ciências Sociais, Trad. Emil. A SOBOTTKA; Giovani Agostini SAAVEDRA. v. 8, n. 1, p. 6879, 2008.

IRAN, Samira. Sustainable fashion: from production to alternative consumption. In: SCHNEIDER, Anna-Maria; JASTRAM, Sarah Margaretha (Orgs.). Sustainable 
fashion: governance and new management approaches. Cham: Springer Nature, 2018, p. 139-159.

JACKSON, Kevin. Natural law, human rights and corporate reputational capital in global governance. Corporate Governance, v. 8, n. 4, p. 440-455, 2008.

Global Corporate Governance: Soft Law and Reputational Accountability. Brook. J. Int'l L., v. 35, n. 1, p. 43-106, 2010.

JIMENEZ, Guillermo C.; KOLSUN, Barbara. Fashion law: a guide for designers, fashion executives and attorneys. New York: Fairchild Books, 2013.

KANT, Immanuel. Antropología. Trad. José GAOS. Madrid: Alianza Editorial, 1991.

KEWELL, Beth. Linking Risk and Reputation: A Research Agenda and Methodological Analysis. Risk Management, v. 9, n. 4, p. 238-254, 2007.

KOHLER, Josef. Manuale delle privative industriali: lehrbuch des Deutschen patentrechts. Mannheim: J. Bensheimer, 1900.

KONTIC, Branislav. Inovação e redes sociais: a indústria da moda em São Paulo. Faculdade de Filosofia Letras e Ciências Humanas da Universidade de São Paulo, 2007.

LEAL, Maria das Graças de. A arte de ter um ofício: liceu de artes e ofícios da Bahia (1872-1996). Salvador: Fundação Odebrecht; Liceu de Artes e Ofícios da Bahia, 1996.

LEWANDOWSKA, Anna; WITCZAK, Joanna; KURCZEWSKI, Przemysław. Green marketing today - a mix of trust, consumer participation and life cycle thinking. Management, v. 21, n. 2, p. 28-48, 2017.

LIMA, Camila Rodrigues Neves de Almeida. Escravos da moda: análise da interveção jurídica em face da exploração em oficinas-moradia de costura paulistana. São Paulo: Lumen Juris, 2016. 
LUCENTE, Giovanna Corrias. La tutela penal della moda made in Italy e le strategie di contraffazione. In: LICHERI, Annaluce; MASSARO, Cristiana (Orgs.). Il codice moda. Roma: Amon, 2015, p. 71-103.

LÜTTENBERG, Thomas. Sempre un passo indrietro rispetto alla moda. In: MUZZARELLI, Maria Giuseppina; CAMPANINI, Antonella (Orgs.). Disciplinare il lusso: la legislazione suntuaria in Itália e in Europa tra medievo ed età moderna. Roma: Carocci, 2003, p. 145-160.

MAGAGNOLI, Stefano. Made in Eataly: identidà e falsificazione. In: Contraffazione e cambiamento economico: marche, imprese, consumatori. Milano: Egea, 2013, p. 71-97.

MAIETTA, Angelo. Il diritto della moda. Torino: G. Giappichelli Editore, 2018.

MANCINI, Cristiane. Responsabilidade social corporativa como instrumento de compliance. In: BECHARA, Fábio Ramazzini; FLORÊNCIO FILHO, Marco Aurélio Pinto (Orgs.). Compliance e direito penal econômico. São Paulo: Almedina, 2019, p. 277-294.

MANZINI, Vincenzo. Trattato di diritto penale italiano. Torino: Unione Tipografico - Editrice Torinese, 1951.

MARQUES, Rafael. Diamantes de sangue: corrupção e tortura em Angola. Lisboa: Tinta da China, 2011.

MARTÍN DE CASTRO, G.; NAVAS LÓPEZ, J. E. La importancia de la reputación empresarial en la obtención de ventajas competitivas sostenibles. Investigaciones Europeas de Dirección y Economía de la Empresa, v. 12, n. 1991, p. 29-39, 2006.

MAYOL, Diógenes. Reputación corporativa y ventaja competitiva. Ensayo a propósito de las cuatro propiedades de Jay Barney. Revista Venezolana de Análisis de Coyuntura, v. XVII, 2011. 
MENDES, Paulo de Sousa. Law enforcement \& compliance. In: Estudos sobre law enforcement, compliance e direito penal. Coimbra: Almedina, 2018, p. 11-20.

MITCHELL, Mark L. The impact of external parties on brand-name capital: the 1982 tylenol poisonings and subsequent cases. Economic Inquiry, v. 27, n. 4, p. 601-618, 1989.

MONTANER FERNÁNDEZ, Raquel. Gestión empresarial y atribución de responsabilidad penal: a propósito de la gestión medioambiental. Barcelona: Atelier Libros Jurídicos, 2008.

MUNGUIRA GONZÁLEZ, Juan. La arquitectura financiera internacional: situación europea y reflexiones en torno a la tipicidad penal. In: DEMETRIO CRESPO, Eduardo; NIETO MARTÍN, Adan (Orgs.). Derecho penal económico y derechos humanos. Valencia: Tirant lo blanch, 2018, p. 420-443.

MURRAY, Jill. Corporate codes of conduct and labor standards. International Labour Organization - ILO, n. March, 1998.

MUZZARELLI, Maria Giuseppina. Guardaroba medievale: vesti e società dal XIII al XVI secolo. Bologna: Il Mulino, 1999.

MYERS, Erika. Justice in fashion: cheap chic and the intellectual property equilibrium in the United Kindom and the United States. AIPLA Quarterly Journal, v. 37, n. 1, p. 47-81, 2009.

NEVES, Roberto de Castro. Crises empresariais com a opinião pública: como evitálas e administrá-las. Rio de Janeiro: Mauad, 2002.

NIETO MARTÍN, Adan. Código ético, evaluación de riesgos y formación. In: NIETO MARTÍN, Adan et al (Orgs.). Manual de cumplimiento penal en la empresa. Valencia: Tirant lo blanch, 2015, p. 135-163.

El cumplimiento normativo. In: NIETO MARTÍN, Adan et al (Orgs.). Manual 
de cumplimiento penal en la empresa. Valencia: Tirant lo blanch, 2015, p. 25-48.

Empresas, víctimas y sanciones restaurativas: ¿como configurar un sistemas de sanciones para personas jurídicas pensando en sua víctimas? In: SAAD-DINIZ, Eduardo; LAURENTIZ, Victoria Vitti (Orgs.). Corrupção, direitos humanos e empresa. Belo Horizonte: D’Plácido, 2018, p. 31-47.

La prevención de la corrupción. In: NIETO MARTÍN, Adan et al (Orgs.). Manual de cumplimiento penal en la empresa. Valencia: Tirant lo Blanch, 2015, p. $307-371$.

La responsabilidad penal de las personas jurídicas: um modelo legislativo. Madrid: Iustel, 2008.

OLIVEIRA, Ana Carolina Carlos de. A responsabilidade por omissão dos sujeitos sensíveis à lavagem de dinheiro: o dever de informar. Universidade de São Paulo, 2016.

PACCIONE, Anais V. On trend: continuing the effort to inspire fashion industry reform and protect underage fashion models. Seton Hall Legislative Journal, v. 41, n. 2, p. 413-436, 2017.

PACHECO, José Wagner Faria. Curtumes. São Paulo: CETESB- Companhia de Tecnologia de Saneamento Ambiental, 2005.

PATROCINIO POLO, Hugo de. Tauromaquia y propiedad intelectual. Madrid: REUS S.A, 2014.

PERINI, Chiara. La tutela penale del lavoratore e del prodotto nella moda. In: Fashion Law: le problematiche giuridiche della filiera della moda. Milano: Giuffrè Editore, 2016, p. 181-207.

POLLINI, Denise. Breve história da moda. São Paulo: Editora Claridade, 2007. POMARES CINTAS, Esther. El delito de trata de seres humanos con finalidad de 
explotación laboral. Revista Electronica de Ciencia Penal y Criminologia, v. 15, n. 13, p. 1-31, 2011.

PRADO, Luiz Regis. Curso de direito penal brasileiro. São Paulo: Thomson Reuters, 2018.

PRADO, Luís André do; BRAGA, João. História da moda no Brasil: das influências às autorreferências. São Paulo: Disal Editora, 2011.

RAGUÉS I VALLES, Ramon. ¿Héroes o traidores? La protección de los informantes internos (whistleblowers) como estratégia político-criminal. Indret: Revista para el Análisis del Derecho, n. 3, p. 1-19, 2006.

RAHMAN, Imran; PARK, Jeongdoo; CHI, Christina Geng-qing. Consequences of "greenwhashing": consumers' reactions to hotels green initiatives. International Journal of Contemporary Hospitality Management, v. 27, n. 6, p. 1054-1081, 2015.

REALE JÚNIOR, Miguel. Art. 149. In: Código penal comentado. São Paulo: Saraiva, 2017, p. 442-449.

REALE JÚNIOR, Miguel. O escravo como não sujeito de direitos. Revista da Faculdade de Direito da Universidade do Porto, v. 8, p. 179-196, 2011.

RIEL, Cees B.M. van; BALMER, John M.T. Corporate identity: the concept, its measurement and management. European Journal of Marketing, v. 31, n. 5/6, p. 340$355,1997$.

ROCK, Michael T. Public disclosure of the sweatshop practices of american multinational garment/shoe makers/retailers: impacts on their stock prices. Competition \& Change, v. 7, n. 1, p. 23-38, 2003.

RODRÍGUEZ MORO, Luis. Tutela pena de la propiedad intelectual. Valencia: Tirant lo blanch, 2012. 
ROJAS RIVERO, Gloria P. Códigos de buenas práticas contra el acoso sexual y acoso moral (artículo 48 LO 3/2007). In: GOÑI SEIN, José (Org.). Ética empresarial y códigos de conducta. [s.1.]: La Ley, 2011, p. 459-486.

RUIZ, Mayra C.; ROMERO, Zilath. La responsabilidad social empresarial y la obsolescencia programada. Saber, ciencia y libertad, v. 7, p. 127-135, 2013.

SAAD-DINIZ, Eduardo. Tutela penal das liberdades pessoais: o tipo penal de redução a condição análoga à de escravo no Brasil. In: SILVEIRA, Renato de Mello Jorge; SALVADOR NETTO, Alamiro Velludo; SOUZA, Luciano Anderson de (Orgs.). Direito penal na pós-modernidade: escritos em homenagem a Antonio Luis Chaves Camargo. São Paulo: Quartier Latin, 2015, p. 159-170.

SAAD-DINIZ, Eduardo. Vitimologia corporativa. São Paulo: Tirant lo blanch, 2019. SALMINEN, Jaakko. The accord on fire and building safety in Bangladesh: A new paradigm for limiting buyers' liability in global supply chains? American Journal of Comparative Law, v. 66, n. 2, p. 411-451, 2018.

SALVADOR NETTO, Alamiro Velludo. Responsabilidade penal da pessoa jurídica. São Paulo: Revista dos Tribunais, 2018.

SAMPER, Luis Fernando. Incorporando los riesgos del siglo XXI en la valuación de marcas. Revista la Propiedad Inmaterial, n. 24, p. 27-51, 2017.

SÁNCHEZ TOMÁS, José. ¿Porqué le llaman trata cuando quieren decir explotación? In: ALCÁCER GUIRAO, Rafael; MARTÍN LORENZO, María; VALLE MARISCAL DE GANTE, Margarita (Orgs.). La trata de seres humanos: persecución penal y protección de las víctimas. Madrid: Edisofer, S. L, 2015, p. 13-18.

SANCTIS, Fausto Martin de. Lavagem de dinheiro por meio de obras de arte: uma perspectiva judicial criminal. Belo Horizonte: Del Rey, 2015.

SCAFIDI, Susan. F.I.T.: Fashion as information technology. Syracuse Law Review, v. 59, p. $69-90,2008$. 
Fashion law: diseñando una nueva disciplina. In: BELLO KNOLL, Suzy Inés; ECHEVERRÍA, Pamela (Orgs.). Derecho y moda. Buenos Aires: Marcial Pons, 2015, p. 17-26.

_. Intellectual property and fashion design. Intellectual Property and Information Wealth, v. 115, p. 115-131, 2006.

Introduction: fashion law triumphant - designing sucess in a new legal field. In: Navigation fashion law: leading lawyers on developing client brands in a changing market and monitoring key legal developments. [s.1.]: Thomson Reuters/Aspatore, 2015.

Towards a jurisprudence of fashion. Fordham Intellectual Property, Media and Entertainment Law Journal, v. XXIX, p. 429-434, 2019.

SEGADE GÓMEZ, José Antonio. EI Secreto industrial (know-how): concepto y protección. Madrid: Editorial Tecnos, 1974.

SEGNALINI, Silvia. Le leggi della moda: guida al diritto per il mondo della moda. Milano: Skira editore, 2012.

SEMPRINI, Andrea. A marca pós-moderna: poder e fragilidade da marca na sociedade contemporânea. Trad. Elisabeth LEONE. São Paulo: Estação das Letras e Cores, 2010.

SENNA, Claudio J. D. Gerenciamento de crises: usando mapas críticos para organizar o que é complexo e caótico. Rio de Janeiro: Alta Books, 2017.

SETHI, S. Prakash. Setting Global Standards: guidelines for creating codes of conduct in multinational corporations. New Jersey: John Wiley \& Sons, 2003.

SHAPIRO, Michelle J.; PATEL, Kiran. Anti-corruption compliance lessons from the Avon settlements. The FCPA report, v. 4, n. 1, p. 1-5, 2015. 
SIEBER, Ulrich. Programas de compliance en el derecho penal de la empresa. Una nueva concepción para controlar la criminalidad econónica. In: ARROYO ZAPATERO, Luis; NIETO MARTÍN, Adán (Orgs.). El derecho penal económico en la era compliance. Valencia: Tirant lo Blanch, 2013, p. 63-109.

SILVA, Camila Borges da. O símbolo indumentário: distinção e prestígio no Rio de Janeiro (1808-1821). Rio de Janeiro: Secretaria Municipal de Cultura, 2010.

SILVA SÁNCHEZ, Jesús-María. Expansión del derecho penal y blanqueo de capitales. In: CALCINA HANCCO, Aldo (Org.). Responsabilidad penal de las empresas y compliance program. Santiago-Chile: Ediciones Olejnik, 2018, p. 177-185.

SILVEIRA, Newton. Propriedade intelectual: propriedade industrial, direito de autor, software, cultivares, nome empresarial e abuso de patentes. Barueri: Manole, 2014.

SILVEIRA, Renato de Mello Jorge. Crimes sexuais: bases críticas para a reforma do direito penal sexual. São Paulo: Quartier Latin, 2008.

— Dimensão penal do trabalho escravo: proteção integral ou evidência de insegurança jurídica. In: SILVEIRA, Renato de Mello Jorge; GOMES, Mariângela Gama de Magalhães (Orgs.). Estudos em homenagem a Ivette Senise Ferreira. São Paulo: LiberArs, 2015, p. 425-449.

Direito penal empresarial: a omissão do empresário como crime. Belo Horizonte: D’Plácido, 2018.

SAAD-DINIZ, Eduardo. Compliance, direito penal e lei anticorrupção. São Paulo: Saraiva, 2015.

SOMBART, Werner. Lujo y Capitalismo. [s.1.]: Coleccion Crisis y Soluciones, 1958.

SOUCHAUD, Sylvain. A confecção: nicho étnico ou nicho econômico para a imigração latino-americana em São Paulo? In: BAENINGER, Rosana (Org.). Imigração 
Boliviana no Brasil. Campinas: Núcleo de Estudos de População (Nepo) - Unicamp, 2012, p. 75-92.

SOUZA, Gilda de Mello e. O espírito das roupas: a moda no século dezenove. São Paulo: Schwarcz, 1984.

SOUZA, Regina Cirino Alves Ferreira. Crimes contra a propriedade industrial. In: SOUZA, Luciano Anderson de; ARAÚJO, Marina Pinhão Coelho (Orgs.). Direito penal econômico: leis penais especiais. São Paulo: Revista dos Tribunais, 2019, p. 176-237.

. Crimes de ódio: racismo, feminicídio e homofobia. Belo Horizonte: D’Plácido, 2018.

Direito da moda: o lado oculto da etiqueta. In: SOUZA, Regina Cirino Alves Ferreira (Org.). Direito da moda: fashion law. Minas Gerais: D’Plácido, 2019, p. 921.

Moda e direito penal: a construção da legislação brasileira sobre joias e a influência de Portugal. In: Direito da moda: vol I. Lisboa: CEDIS, 2019, p. 139-155.

SOUZA, Deborah Portilho Marques de. A propriedade intelectual na indústria da moda: formas de proteção e modalidades de infração. Instituto Nacional da Propriedade Industrial, 2015.

SOUZA, Luciano Anderson de. Crimes contra a administração pública. São Paulo: Revista dos Tribunais, 2018.

Direito penal: parte especial - arts. 121 a 154-B do CP. São Paulo: Revista dos Tribunais, 2019.

. Direito penal: parte geral. São Paulo: Revista dos Tribunais, 2019.

SOUZA, Regina Cirino Alves Ferreira. Tratamento penal da violação de direito 
autoral e o caso da indústria da moda. Revista Fórum de Ciências Criminais - RFCC, v. 4, n. 8, p. 33-48, 2017.

STEIN, Stanley Stein. Origens e evolução da indústria têxtil no Brasil - 1850/1950. Trad. Jaime Larry BENCHIMOL. Rio de Janeiro: Editora Campus, 1979.

TEIXEIRA, Patrícia B. Caiu na rede. $\mathbf{E}$ agora? Gestão e gerenciamento de crises nas redes sociais. São Paulo: Évora, 2013.

TERRADILLOS BASOCO, Juan María. Explotación laboral, trabajo forzoso, esclavitud ¿Retos político-criminales para el siglo XXI? In: DEMETRIO CRESPO, Eduardo; NIETO MARTÍN, Adan (Orgs.). Derecho penal económico y derechos humanos. Valencia: Tirant lo blanch, 2018, p. 215-243.

TIMÓTEO, Gabrielle Louise Soares. Os trabalhadores bolivianos em São Paulo: uma abordagem jurídica. Faculdade de Direito da Universidade de São Paulo, 2011. - Trabalho em condições análogas à escravidão e a indústria da moda. In: SOUZA, Regina Cirino Alves Ferreira (Org.). Fashion law: direito da moda. São Paulo: D’Plácido, 2019, p. 167-188.

TRUZZI, Oswaldo Mário Serra. Etnias em convívio: o bairro do Bom Retiro em São Paulo. Estudos Históricos, v. 27, n. 27, p. 143-166, 2001.

SACOMANO NETO, Mário. Economia e empreendedorismo étnico: balanço histórico da experiência paulista. RAE, v. 47, n. 2, p. 37-48, 2007.

VANCE, Patricia de Salles. Reputação corporativa: uma revisão teórica. Revista de Gestão USP, v. 14, n. 4, p. 93-108.

WHYTE, Joana. Direito da concorrência à la mode. In: ABREU, Lígia Carvalho; COUTINHO, Francisco Pereira (Orgs.). Direito da moda: vol I. Lisboa: CEDIS, 2019, p. 199-227. 
WILLIAMS, James W. Reflections on the private versus public policing of economic crime. British Journal of Criminology, v. 45, n. 3, p. 316-339, 2005.

WILSON, Elizabeth. Enfeitada de sonhos: arte e comunicação. Trad. Maria João FREIRE. Rio de Janeiro: Edições 70, 1989.

WRIGHT, S L et al. Atmospheric microplastic deposition in an urban environment and an evaluation of transport. Environment International, n. September, p. 1-7, 2019.

ZÚÑIGA RODRÍGUEZ, Laura. Responsabilidad penal de las personas jurídicas y derechos humanos: una valoración desde la reforma de 2015 de la legislación española. In: DEMETRIO CRESPO, Eduardo; NIETO MARTÍN, Adan (Orgs.). Derecho penal económico y derechos humanos. Valencia: Tirant lo blanch, 2018, p. 87-110.

Americans on globalization: a study of US public attitudes. Program on International Policy Attitudes, 2000.

Contrefaçon \& terrorisme: rapport 2016. Union des fabricants - UNIFAB, p. 1-30, 2016.

Corruption \& labor trafficking in global supply chains. White Paper, p. 1-8, 2013. 